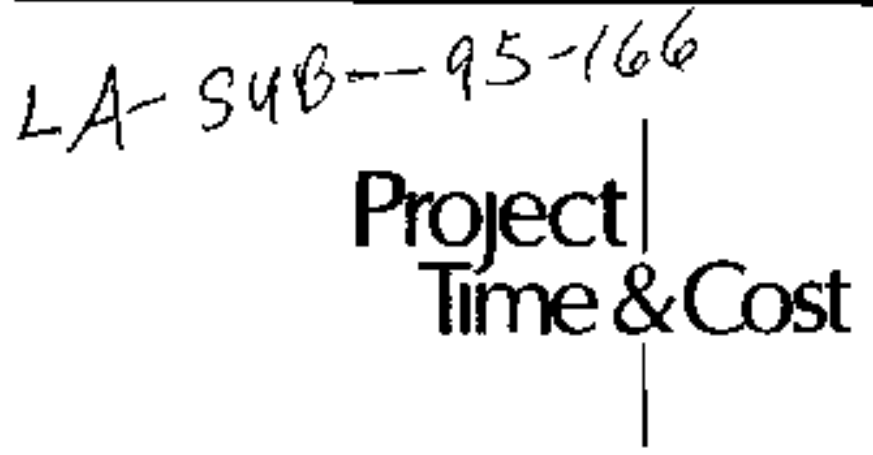

\title{
PROJECT MANAGEMENT SUPPORT AND SERVICES FOR THE ENVIRONMENTAL RESTORATION AND WASTE MANAGEMENT
}

FINAL REPORT SUBCONTRACT 9-XG-8822F-1

APRli 10, 1995

\section{DISCLAIMER}

This report was prepared as an tocount of watk sponsored by an agency of the United Sintes Government. Neither the Uniked Sintet Gowernment nor any ajebcy thereof, wot aty of Iheif

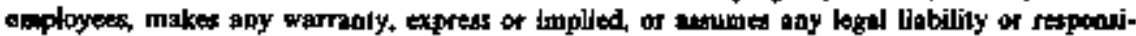

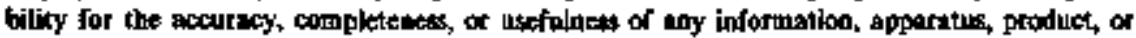

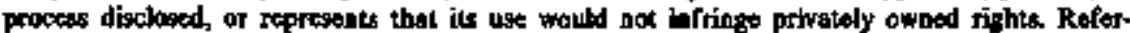

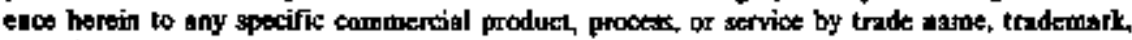
minufacturer, or otherwise does ond necersarily contiatute or imply fis eadorsement, reco:mendation of faworing by the Unitat States Gowernment of any agapcy thereof. The viem

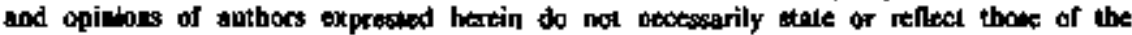
Uuited Stalles Govenmona or any arency thereof

\section{MASTER}

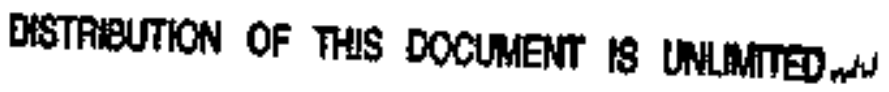




\section{DECLAMIXR}

Portions of this docoment may be fllegible in electronic image produets. Images are produced frum the best avilahle original dociment. 


\section{TABLE OF CONTENTS}

Abstract

Page 1

Final Report

Page 2

Appendix A 


\begin{abstract}
The Los Alamos National Laboratory (LANL) Environmental Restoration Technical Support Office (ERTSO) contracted Project Time \& Cost, Inc. (PT\&C) on 16 November 1992 to provide support services to the U.S. Department of Energy (DOE). ERTSO had traditionally supported the DOE Albuquerque Office in the Environmental Restoration and Waste Management Programs and had also supported the Office of Waste Management (EM-3O) at DOE Headquarters in Gemantown, Maryland. PT\&C was requested to provide project management and support services for the DOE as well as liaison and coordination of responses and efforts between various agencies. The primary objective of this work was to continue LANL's technical support role to EM-30 and assist in the development of the COE Cost and Schedule Estimating (CASE) Guide for EM-30.
\end{abstract}

PT\&C's objectives, as specified in Section B of the contract, were well met during the duration of the project through the review and comment of various draft documents, trips to DOE sites providing program management support and participating in the training for the EM-30 Cost and Schedule Estimating Guide, drafting memos and scheduling future projects, attending numerous meetings with LANL, DOE and other subcontractors, and providing written observations and recommendations.

The results obtained were detemined to be satisfactory by both the LANL ERTSO and DOE EM-30 organizations. The objective to further the support from LANL and their associated subcontractor (PT\&C) was met. The contract concluded with no outstanding issues. 


\section{FINAL REPORT}

The Los Alamos National Laboratory (LANL) Environmental Restoration Technical Support Office (ERTSO) contracted Project Time \& Cost, inc. (PT\&C) on 16 November 1992 to provide support services to the U.S. Department of Energy (DOE). ERTSO had traditionally supported the DOE Albuquerque Office in the Environmental Restoration and Waste Management Programs and had also supported the Office of Waste Management (EM-30) at DOE Headquarters in Germantown, Maryland. The primary PT\&C resaarcher on this task, Marc A. Zocher, was requested to provide "a wide range of short duration project management support and services for the DOE" as well as "Ilaison and coordination of responses and efforts between various agencies." A significant amount of support was expected to occur at the DOE Germantown, Maryland location.

PT\&C's objectives under this contract, as specified in Section B of the contract, and further described in Appendix B, Statement of Work, consisted of:

1.0 Rapid Response Capability - to provide rapid response project management capability.

2.0 Implementation Review Coordination - to provide implementation review coordination as requested.

3.0 Meeting Attendance - to attend meetings a requested in order to aid in probtem identification and solution.

4.0 Project Management Services - to provide program/project management services as requested.

5.0 Reports - to provide reports including findings and recommendations.

Beginning in November 1992, the first task performed under this contract consisted of review and comment on the Draft EM-30 Cost Estimating Guide prepared for the Office of Waste Management. This task was completed on November 19, 1992. The second task included a trip to Richland, Washington to determine needed program management support on the Tank Waste Remediation System (TWRS). This trip involved meetings with Westinghouse Hanford (WHC), LANL, and PT\&C personnel. A memorandum was submitted to Gene Higgins (DOE-RL) November 11, 1992 detaiting PT\&C's observations and recommendations for rebaselining TWRS. Subsequently, a trip was made to Oak Ridge National Laboratory (ORNL) in Oak Ridge, TN to complete this work.

In December 1992, the trip to ORNL by PT\&C and LANL personnel involved a review of an independent check estimate (ICE) prepared for the Oak Ridge TSCA Incinerator Operations. A follow-up meeting was scheduled for January 1993. PT\&C also assisted the DOE EM-333 personnel in Germantown, MD in drafting memos and scheduling future projects. A meeting was attended by PT\&C, LANL and other subcontractors to discuss the EM-30 Cost Guide. PT\&C and LANL also attended the first pilot training of the EM-30 Cost Estimating Guide in Kansas City. Additional tasks 
inctuded sorting and filing information and dala shipped from DOE Headquarters to the PT\&C project office in Albuguerque, NM.

The tasks in January 1993 centered around two major activities. The first task involved participation in the training for the EM-30 Cost and Schedule Estimating Guide and associated site visits at DOE in Idaho, Weshington and California. The second task involved program management support at DOE-RL on the Tank Waste Remediation System (TWRS) Program at Richland.

Tasks in February 1993 included the participation of PT\&C personnel in the EM-30 Cost Guide Training in Albuquerque. PT\&C personnel also travelled to EM-30 Headquarter offices in Germantown to begin scheduling the EM-30 Progrem Cost Reviews (PCRs), continuing the following week at LANL. A preliminary scope document was prepared for the PCRs and meetings were held in Los Alamos to discuss roles and responsibilities. A draft review schedule was prepared based on meetings with eighteen EM-32 Program Managers. PT\&C personnel also participated in the EM-30 Industry Support Experts (ISE II) forum in Washington, DC to discuss industry and DOE partnerships.

During March 1993, activity occurred on the review of the EM-30 Cost Guides. At Richland, DOE-RL requested review of the current Purex Plant scope, schedule, and estimates for the shutdown of Purex.

LANL has been able to continue supporting EM-30 as a follow on to this contract. LANL ERTSO representatives provided project management support and policy analysis assistance. This support exceeded the original objective of temporary DOE help os the ectivity continues from LANL at present.

While no formal publications were made under this subcontract, PT\&C personnel provided monthly status reports and frequent memoranda and letters to LANL and DOE-RL personnel reporting project status, observations and recommendations, and presenting prepared schedules, manuals, and scope of work proposals. Copies of the monthly status reports and representative letters/memoranda are attached to this report as Appendix A. Additional materials are available upon request.

The primary objective of this work was to continue LANL's technical support role to EM-30 and assist in the development of the DOE Cost and Schedule Estimating (CASE) Guide for EM-30. The results obtained were determined to be satisfactory by both the LANL ERTSO and DOE EM-30 organizations. The objective to further the support from LANL and their associated subcontractor (PT\&C) was met. The contract concluded with no outstanding issues. 
APPENDIX A 


\title{
Project Time \& Cost
}

\author{
U.S. Department of Energy \\ Los Alamos National Laboratory \\ Project Management Support and Services \\ For the Environmental Restoration \\ and Waste Management Program
}

Contract No. 9-XG3-8822F-I

Monthly Status Report

for Noventer, 1992

January 4 * 1993 


\section{Project Time \& Cost}

Status Report for Peri,od Ending November 30, 1992

The subcontract between Los Alamos National Laboratory (LANL) and Project Time \& cost. Inc. (PTsC) was signed in Los Alamos on November 16,1992 .

The total manhours expended during November are:

$\begin{array}{lr}\text { Principal } & 0 \text { Hours } \\ \text { Manager } & \mathbf{3 2} \text { Hours } \\ \text { Clerical } & 0 \text { Hours } \\ \text { Total } & 32 \text { Hours }\end{array}$

This compares with a planned expenditure of 2 hours principal, 40 hours manager, and 20 hours clerical for the time period of November 16 through November 30, 1992.

The first task under this contract consisted of review and comment of the draft EM-30 cost Estimating Guide prepared for the office of waste Management. This task was completed on Novenber 19,1992 .

The second task involved a trip to Richland, WA with EANL to determine needed program management support on the Tank waste Remediation System (TWRS). This trip began on November 17, 1992 and ended on November 19, 1992, This trip involved meetings with Hestinghouse Hanford (WHC), LANL, and PT\&C personneI.

The third task involved the start of a trip on November 30, 1992 to Oak Ridge National Laboratory (ORNL) in Oak Ridge, Tennessee. The details of this task are covered in the December monthly report.

Locations visited:

Los Alamos National Laboratory Hanford Site, Richland, iA Oak Ridge National Laboratory
Dates:

$11 / 16$

$11 / 17-11 / 19$

$11 / 30$ 


\section{Project Time \& Cost}

U.S. Department of Energy

Los Alamos National Laboratory

Project Manegement Support and Services

for the Environmental Restoration

and Waste Management Program

Contract No. 9-XGJ-8822F-1

Monthly Status Report

for December. 1992

January 4, 1993 


\section{Project Time \& Cost}

Status Report for Period Ending December 31, 1992

This subcontract, signed Noverber 16, 1992, was in effect for the full month of Decenber. The total manhours expended during December are:

$\begin{array}{lr}\text { Principal } & 0.0 \text { Hours } \\ \text { Manager } & 131.0 \text { Hours } \\ \text { Clerical } & 17.5 \text { Hours } \\ \text { Total } & 148.5 \text { Hours }\end{array}$

This compares to a planned rate of 4 hours principal, 88 hours manager, and 40 hours clerical for the time period of December 1 through December 31, 1992. Although LANL is officially closed from Decenber 25, 1992 through Ianuary 3, 1993, PT\&C was operating during that time.

The first task for December was a meeting at oak Ridge National Laboratory (ORNL) on December 1, 1992. This meeting involved the review of an independent check estimate (ICE) prepared for the Oak Ridge TSCA Incinerator Operations. This all day meeting resulted in follow-up discussions and a plan to meet again in January. 1993.

The second task began on December 2, 1992 and involved work at DOE Headguarters in Germantown, MD until December 4, 1992. This task included items under subcontract category 1.0 Rapid Response Capability, and 3.0 Meeting Attendance. The PT\& Manager assisted the DOE EM- 333 personnel in drafting memos and scheduling future projects. On Friday, December 4, 1992, a meeting was held at the Bellemead building in Germantown, MD to discuss the Ef-30 Cost Guide. This meeting was attended by representatives from PT\&C, LANL, and other subcontractors.

The third task accomplished at various times during December included sorting and filing of information and data shipped from DOE Headquarters in Gemmantown. MD to the PT\&C project office in Albuquerque, MM.

The fourth task involved a trip to the Kansas city plant on December 9, through December 11, 1992. This was also attended by a LANL representative. The purpose of the trip was to attend the first pilot training of the EM- 30 cost Estimating Guide. 


\section{Project Time \& Cost}

The fifth task commenced on December 14, 1992 and involved a two day meeting with aM-30 and EM-60 personnel (DOE and contractor) at Hanford. This series of meetings involved the transfer of landlord activities from EM-30 to EM-60 and was run by Jin Keenan (EM-34).

The sixth task involves continued progrem support for the Hanford Tank Heste Femediation System (TWRS) and began with another trip to Hanford on December 20 through December 23, 1992. This trip was specifically planned to outline additional help from LANL to DOE/RL and involved meetings, briefings, and discussions wth Westinghouse Hanford and DOE/RL.

The last tagk for December was the first activity under the TwRs plan that began December 23, 1992 and involves the writing of a TWRS specific cost guide. This task will continue in January. 1993 .

Locations Visited:

Oak Ridge National Laboratory

DOE Headquarters, Germantown, MD

Kansas City Plant

Hanford site, Richland, WA

Hanford site, Richland, WA
Bates:

$12 / 01$

$12 / 02-12 / 04$

$12 / 09-12 / 11$

$12 / 14-12 / 16$

$12 / 20-12 / 23$ 


\section{Project Time \&Cost}

PROJECT TIME \& COST, INC. 6501 Amerlcas Parkwzy, N.E. Suite 665 Abuquerque, New Mexico 87110

(505) $884-2929$ FAX (505) 884-7672

February 01, 1993

University of California

Los Almaos National Laboratory

ATTN : R.N. Tokay

REF : 9-XKG3-8822F-1

P.O. Box 990 MS P274

Los Alamos, New Mexico 87545

Dear Ron:

Enclosed is the monthly report for January, 1993 under

subcontract No. 9-XG3-8822F-1 which originated November 16, 1992.

If you have any guestions, please do not hesitate to call.

Sincerely,

PRONECT TIME \& COST

Marc A. Zocher

Hanager, Western Operations

Enclosures

cc: Gary Thompson, LANL

MAZ $: 1 j$ 


\author{
U.S. Department of Energy \\ Los Alamos National Laboratory \\ Project Management Support and Services \\ for the Environmental Restoration \\ and Waste Management Program
}

Contract No. 9-XG3-8822F-1

Monthly status Report

for January, 1993

February 1, 1993 


\section{Status zoport for Poriod ending January 31, 1993}

This subcontract, signed November 16, 1992, was in effect for the full month of January. Total manhours expended during January are:

$$
\begin{array}{ll}
\text { Principal } & 3.0 \text { Hours } \\
\text { Manager } & 159.0 \text { Hours } \\
\text { Clerical } & 60.0 \text { Hours } \\
\text { Total } & 222,0 \text { Hours }
\end{array}
$$

This compares to a planned rate of 4 hours principal, 88 hours manager, and 40 hours clerical for the time period of January 1 through January 31, 1993.

The tasks in January centered around two major activities. The first task involved participation in the training for the EM-30 Cost and Schedule Estimating Guide and associated site visits at $\mathrm{DOE}$ in Idaho, Washington and California (see Locations Visited). This was a planned and scheouled activity, and will continue in February.

The second task involved program management support at DOE-RL, specifically on the Tank Waste Remediation System (TWRS) Program at Richland. This task was approved as an activity by EM-TSO. in conjunction with DOE-HQ. Approximently 60\% of the hours worked in January are associated with that task. TWRs work has stopped, by direction of LANL EM-TSO, on Friday, January 29, 1993, and will continue in February if woxk authorization is received.

Locations visited

Idaho Falls, ID (DOE-ID)

Richland, WA (DOE-RL)

Richlarid, WA

Richland, WA

Oakland, CA (DOE-SAN)
Dates
$1 / 4-1 / 5$
$1 / 6-1 / 7$
$1 / 12-1 / 16$
$1 / 18-1 / 20$
$1 / 21-1 / 22$ 
PROIECT TIME \& COST, INC.

March 5, 1993

University of California

Los Alamos National Laboratory

ATTN: R.N. Tokay

REF: 9-XG3-8822F-1

P.O. Box 990 MS P274

Los Alamos, New Mexico 87545

Dear Ron:

Enclosed is the monthly report for February, 1993 under subcontract No. 9-XG3 $-8822 F-1$ which originated November 16,1992 . We have continued to provide services under this contract at an accelerated rate due to the tasks assigned by LANL EES-14. We will keep Gary Thompson appraised of the situation to avoid any cost overnuns.

If you have any questions, please do not hesitate to call.

Sincerely,

PROJECT TIME \& COST

Marc A. Zocher

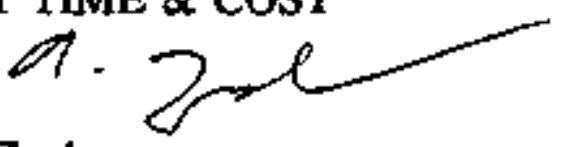

Manager, Western Operations

MAZ:bg

Enclosure

cc: Gary Thompson, LANL 


\author{
U.S. Department of Energy \\ Los Alamos National Laboratory
}

Project Management Support and Services

for the Environmental Restoration

and Waste Management Program

Contract No. 9-XG3-8822F-1

\author{
Monthly Status Report \\ for February, 1993
}

March 5, 1993 


\section{Status Report for Period Ending February 28, 1993}

The subcontract between Los Alamos National Laboratory (LANL) and Project Time \& Cost, Inc. (PT\&C) was signed in Los Alamos on November 16, 1992.

The total manhours expended during February, 1993 are:

$\begin{array}{lll}\text { Principal } & 3.5 & \text { Hours } \\ \text { Manager } & 148 & \text { Hours } \\ \text { Clerical } & 8 & \text { Hours } \\ & & \\ \text { Total } & 159.5 \text { Hours }\end{array}$

The first task for February involved the participation in the EM-30 Cost Guide training in Albuquerque. This was the last planned session and follows other sessions attended at Idaho, Richland, and San Francisco under this contract.

The second task involved travel to EM-30 Headquarter offices in Germantowa to begin to schedule the EM-30 Program Cost Reviews (PCR's). This task continued the following week at LANL. A preliminary scope document was prepared for the PCR's and meetings were held at Los Alamos to discuss roles and responsibilities. This task continued the following week and a draft review schedule was prepared based on meetings with eighteen EM-32 Program Managers.

The third task involved participation in the EM-30 Industry Support Experts (ISE II) forum in Washington, DC. The meeting was held to discuss industry and DOE partmerships.

Locations Visited:

Dates:

Albuquerque, NM - EM-30 Cost Training

Los Alamos National Laboratory

$2 / 2-2 / 3$

Germantown, MD

$2 / 16-2 / 19$

$2 / 7-2 / 12$ and $2 / 22-2 / 26$ 
PROJECT TIME \& COST, INC.

\section{Project Time \& Cost}

April 12, 1993

University of California

Los Alamos National Laboratory

ATTN: R.N. Tokay

REF: 9-XG3-8822F-1

P.O. Box 990 MS P274

Los Alamos, New Mexico 87545

Dear Ron:

Enclosed is the monthly report for March, 1993 under subcontract No. 9-XG3 $8822 \mathrm{~F}-1$ which originated November 16, 1992. Activity slowed for the month of March due primarily to the slippage of the Program Cost Reviews in EM-30.

If you have any questions, please do not hesitate to call.

Sincerely,

PROJECT TIME \& COST

Mave C. Boctece

Manager, Western Operations

MAZ:bg

Enclosure

cc: Gary Thompson, LANL 


\title{
U.S. Departrnent of Energy \\ Los Alamos National Laboratory
}

Project Management Support and Services for the Environmental Restoration and Waste Management Program

Contract No. 9-XG3-8822F-1

\author{
Monthly Status Report \\ for March, 1993
}

April 12, 1993 
Status Report for Period Ending March 31, 1993

The subcontract between Los Alamos National Laboratory (LANL) and Project Time \& Cost, Inc, (PT\&C) was signed in Los Alamos on November 16, 1992.

The total manhours expended during March, 1993 are:

$\begin{array}{lrl}\text { Principal } & 0 & \text { Hours } \\ \text { Manager } & 71 & \text { Hours } \\ \text { Clerical } & 1 & \text { Hours } \\ & & \\ \text { Total } & 72 & \text { Hours }\end{array}$

Activity slowed on the contract due to the slip in the schedule for the Program Cost Reviews (PCRs) planned to start in March. Activity occurred on the review of the EM-30 Cost Guides. This work was originally planned for February, but slipped out due to the heavy workload on other tasks.

At Richland, DOE-RL, requested review of the current Purex Plant scope, schedule and estimates for the shutdown of Purex. This activity will conclude in April with a status report and recommendations.

Locations Visited:

Dates:

Richland, WA

$3 / 24-3 / 26$

$3 / 31-4 / 02$ 
November 19,1992

TO: Gene Higgins, DOE-RL

FROM: $\quad$ Marc Zocher, Project Time \& Cost

Gary Thompson, LANL

RE: OBSERVATIONS AND RECOMMENDATIONS

Thank you for the opportunity to come visit TWRS and look at the major project you have tunderway in the rebaselining of TWRS. The staff from WHC was helpful and the visit quite productive.

The following observations were made: ,

o Presently, no real overall baseline exists for TWRS

o A dedicated team has been formed to address the rebaselining

- The TPA is the primary driver for the schedule, and DOE is the primary customer for the rebaselined product

o The WHC financial system is robust enough to handle major project control issues

- A culture change needs to occur, training needs to happen, and the end result is a site with self-sustaining resources to manage, plan, estimate, and schedule TWRS activities

- site specific procedures are needed to maintain continuity and have a base for understanding customer requirements

- A rebaseline will be successful if 1) the effort meets the stated goals this year and, 2) procedures and resources are in place to replicate the activity in the future

The following recommendations are based on observations to date:

- Develop one representative ADS through to completion in the early January timeframe (In parallel, keep the effort on the other end functions moving). Present 


\section{INFORMAL MEMORANDUM}

January 7,1993

Via Facsimile

TO: Renee Finke, WHC

FROM: Mare Zocher, Projoct Time \& Cost

RE: $\quad$ Draft TWRS Cest Estimating Guide

I am forwarding the first sections of the TWRS Cost Estimating Guide for your review. As you know, we originally agreed to a date of January 5, 1993 for delivery of the first draft, and the inclusive dates of January 3-7 were set aside for activities directed by EM-333. The current planned schedule slip is based on the loss of three working days during the week of December 29. Approximately $40 \%$ of the text and thiting is complete to date, and $90 \%$ of the TWRS material review was compeled prior to January 1. I have also sterted development of the slides and handouts for the class next week.

I need some information from you that will assist me in continuing both the presentation and the guide. Specifically -

- What is the desired length of the training? I am planning for two hours with one additional hour for questions. Please redirect duration, if needed.

- How large and who is the intended audience? Will I need to give a short briefing on the HQ guidance prior to the talk?

- Please choose one real TWRS activity that would make sense for an example for the class. Does any one stand out in your mind as a representative ADS?

- I briefly met and spoke with the gentleman (Lynn McMahn \{sp\}) from Mactec about the "desktop guide" he is preparing. Could you get some more information on that effort and how it relates to this guide? If you wish, just send me his phone number and I will call him.

- I am also sending you a copy of the latest review criteria that will need comments and modification to fit TWRS and section 6 of the Guide. Please review and comment on this section as well.

- The agreed date for the training was Wednesday the 13th. Gary indicated that Thursday might be acceptable to you, and you said that Fridays are not great. What is your preference? 
I will be unavailable on Friday morning, but you can fax answers/comments to (505) 829 3143. I will not know my schedule for next week until the afternoon (Based on AM appointment). You can also reach my secretary at (505) 884-2929 and I will call in for mestages.

I understand from Gary Thompson that the current acreement with EM-333 is to allow funding for this project to continue umtil January 15, 1993. Any help you can lend to that process is grastly appreciated, since I currently do not have any intemal help under contract to provide assistance on this project.

CC:

Gary Thompson, LANL EM-TSO

Gene Higgins, DOE-RL

Ken Roberts, PT\&C 


\section{Outline Draft 1,0}

TWRS Cost Estimating Handbook

for Operations Activitios

I. Introduction

Purpose

Intended Audience

Introduction to Cost Estimating for TWRS Operations

II. General Requirements

Description of the overall estimating requirements for TWRS and the role of estimates in the planning process.

III Scoping TWRS Activities

Includes the importance of estimate back-up documentation, the type of information required, and the formats for input.

IV. Scheduling TWRS Activities

This section covers scheduling as it relates to estimating process. In-depth discussion of scheduling will not bs addressed.

V. Estimating TWRS Activities

The primary focus of the document, this section will cover the application of ABC estimating to TWRS optations. ACT 1 IT/ES.

VI. Self-assessment Criteria and Process

$$
\text { ster }
$$

This section deals with the peer review concept and sets up criteria for checking the completeness and quality of the TWRS estimates.

VII. Example estimate

A TWRS estimate, on the appropriate forms, will be included to illustrate the concepts outlined in the guide.

Appendix A.

TWRS Activity Dictionary 
PROJECT TIME \& COST, INC.

6501 Americas Parkway, N.E. Suite 665

Project Time \& Cost

Albuguerque, New Mexico 87110

(505) 884-2929

FAX (505) B84-7672

January 29, 1993

Nestinghouse Hanford Conpany

TWRS Baseline Development Tean

1305 vansfleld, Sutte 6

Richland, wh 99352

Attention: $\mathbf{H a}$. Renee Finke

Subject: DRAFT MANUALS

Dear Ronee:

Transmitted herewith is the first draft of the Tank Waste Romediation syston cost Estimation vanual. I have put under separate binder, the Cogt Esttmats Valfidation and Reviens and cost Bgt dmation standaras and practices. I would appreciate you giving one set to DOE RL for their concurrent review.

Ae you and I have diecussed, I would appreclate comments back no later than Honday, February 8, 1993, this will allow you a full work week to review the documents.

I have not yet completed full eample estinate for your raviow. I would like to ure a real TwRs example because the generic estimate I have produced on tank farms will not contain activities familiar to preparers of the THRS estimates. I teel that a sample estimate is best completed in Richland when I come up to complete the task with Ien Hclyahon on the desk-top audit section.

If you have any questions, please do not hesitate to contact me.

Regards,

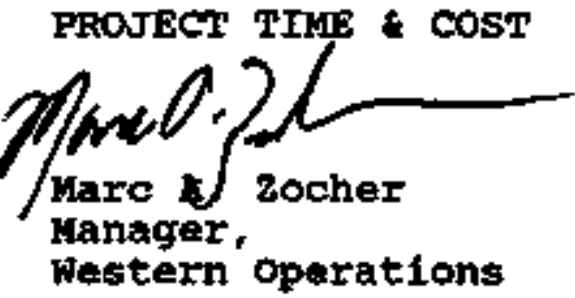

cc w/a: Gary Thonpson, LANL BM-TSO 


\section{U.S. Department of Energy}

DOE Hanford Reservation

\section{Tank Waste Remediation System}

(TWRS)

\section{COST ESTIMATION MANUAL}

- Cost Estimate Validation and Reviews -

Draft 1.0

January, 1993 
WESTINGHOUSE HANFORD COMPANY

TWRS COST ESTIMATION MANUAL
Manual

Soction

Page

Effective Date

Orgenization
WAC.CM.X.X

$\mathrm{XX}, \mathrm{REV} \mathrm{X}$

1 of XX

DATE

Level $t$ aoro/Level 2 org

TITLE:

Approved by

COST ESTIMATE VALIDATION AND REVIEWS

XXXX, Manager

$\mathbf{X X X X}$

\subsection{PURPOSE}

To introduce the policies, practices and anohods for conducting self-assessnent and cost estimate reviews by Westinghouse Hanford Company on the TWRS baseliase. These methods include geer review, mock review, independent cheol estimates, benchnorking and other self-tassessment techniques. The ultimale purpose of employing these texbmiques is to arrive at ereditble, defensible cost estimates that meet WhC quility objectives on an ongoing besis. Other techniques for assessing projegt performance against a baseline, such as desk performance audits on milestone or oost element attoinment, ore slso included.

A central theme of the intemal assessmept and neview process promoted by DOE EM-30 is the desirability of cepturing issaes, findings, and recommendations from lower level reviews ood passting such information up to the next highess level of teview. Higher level roviews in the past were often conduoted by reviewers who did not have aepess to the results of lower levej reviews. This practice, partialty the result of review schedale constrajnts and partially the result of poor comminrication, often resulted in the same issues being covered by severst differeat review orgenizations and in lower and highe level reviews beimg conducted at a similar level of detril.

A cosa estimate review, as defined in DOE Order 5700.2D is:

-4 review of a previous estimate for completeness, reasonableness, and consistency. The controleteness relates to the inslusion of all relevant costs. Reasonableness relates to a bajance between discernible optimisen and pessimism in the estimate. Consistency relates to the general acceptability of applied ground sules ot the exployment of the same methods in going from one estimate to another. A review may be accomplished by comparing the estimate to an independent estimnte; however, revievers generally will not bave these availatle. Therefore, cost reviewers will generally use suth toots as historical nutes of thumb to check unil prices, parsmotric cost estimatíng relationships, snd sampling. Also, the estimate can be exemined for appropriateness and consistency."

\subsection{Applicability}

This section is applicable to all planped work activities under the TWRS Division Charter (09/03/92). This includes the Woste Tank Project, Tank Waste Safoty and Technology. Tank Waste Disposal, TWR Projects/HWVP, TWR Program Integration, and Business Manegement and Adninistration. Both TWRS prograss and project elements are coverod. 
The major oetf-asessment lechriques described berein are peer reviow, moek review, check estinates, benchmarking, and desk performance sudits. All five methods can be empkyed singularly or in concent depending on the size and complexity of the work elenents under review.

The use of a peet review process was stgeested in the Oftice of Waste Managenent (EM-30) Cost and Schodule Estipnting Gujide, Working Draft (12/08/92) as a means of chocking estimate format and content quality. The guidence for conducting infiependent estimate reviews (ICERs) in the Geseral Procedures for Preparing Cout and Schedule Estimates and Conducting Independent Estimate Reviews for the Five-Year Pkan is the same as the definition for a peer roview, described below. When conducting the peer review, no kss than $80 \%$ of the cost mormbers should be reviewed for any given estimate.

\subsection{Definition}

A pees review is a review conducted by a group of estimalors and technical advisors that did not work on the originat ostimate, but are an advocale of the activity. For TWRS, this would include team members from both Westinghouse Hanford and contractors to Westinghouse, as sppropriate.

\subsection{Purpose}

The primary purpose of the peer review is 10 providio an internal, quality control mechenisan on the production of TWRS estimntes. The secondary purpose is to provide a perr reviow doctument that is then avaituble for other internal and external reviewers to base their reviews op. This will sllow for more productive reviows from other parties and an sudit and quality contzol trail on the TWRS extimates.

\subsection{Procedure}

The peer review procedure is besed on a standard reviow checklist as shown in Appendix A. This checklist is used to document the basis, type, and preparation of the seope, solnedule and cost components of the ostimate. It is possible to review just one somponent, such as scope, at one pees review session. The interaction of the three components (scope, schedule \& cost) sannot be ascertained using that method, bowever.

The procedure is broken into the following activities:

o determining the estimate(s) that will be reviewed;

- selecting the periew tearn, including tesm leader and roport genterator,

o creating a short sope and schedule of the peer review;

- scheduling the review session;

o studying the estimate material, ipelufing back-up documentation and sommery information (suoh as the Activity Dats Sheet);

- prepering for the meting;

- condueting the review metting; and

o preparing and dissemituating the peet review report.

The review meeting duration will depend on the aumber of extimntes under review, as well as the seope (full or purtial) of the reviow. As a rule, ont-half to one hour should be spent briefing the review tenth on the history and beckground of anoh eatimate ta be reviewed. The checklist stould be completed prior to the review by the individuals boing teviewed (deienders) so that ench section can be exarnined in an expeditious and thotough 
manner by tho petr review tean. The review can then proeeed bosed on exception to compliance and an explangtion of areas of noncomplianee within the review criteria. As an exampie, the question may ask for the estimate grocific Work Breakdown Strutture (WBS) and the defepders will have it aveilable for review. By haviog the checklist ahead of time, these questions can be anticipated and the vesponse organized by the defending group. If an answer is " $\mathrm{No}$ " or "N/A" to a question, the teams should be prepered to discust turd explatin theace andwert.

\subsection{Documentation Requirements}

A repon shall be prepared after each peer review and one copy shall remain with the cost estinate as a record of the review. The report will onntain:

- The aame of the tearn members;

a the dale, agende, scope and reason for the review,

- the tome and date of the report peparer.

a general description of the scope, schedule and estimate;

- $\quad$ list of findings;

a list of recommendalions besed on these findings,

o In appendix with the completed teview sheets; and

- in eppeodix with the resumes and qualifietions of the review tean members.

The word "mock" is used to show that this review is copducted under the exact conditions of an upcoming review or validation, except thot the parties conducting the review are jntemel personnel assigned in the role of "reviewers". If a different checklist will be used for the upooming reviews (as is often the care), this checklist should be obtained as soon 4 s passible and used it the mock review. The idea is to simulete the review to both entance the quality of the estimate and to ty out conmunisation techniques and doctmentation forthats.

\subsection{Defrinition}

A mock review is an internal review with the sole purpose of gatrging readiness for an upconing internti (es., DOE-RL) or externgl (e.g., OMB) roview or validation. It is conducted as a two tekm approach whereby one team takes on the reviewer cole while the actual team that will be reviewed in the upcoming session participates as if the astinal review was bejing conducted.

\section{$4.2 \quad$ Purpose}

As stoted in 4, $\mathrm{t}$, the primary purpose of the mock rtview process is 10 assess teadiness for upconing internal or external reviows. The expected outcome of a mock review is a better understanding of aress of deficiencies ukat are either progranmatic or specific to one estimate under review. It should be conducted after a peer review has been completed on the extimate and the peer teview findings have been inconporatod. By showins a corrective antion pian on the remaining ftadings from the nock review, the negative findings on the rest reviow can be miniznized.

\subsection{Procedure}

Depending on the size and scope of the upsoming review, the mock review will be conducted in a very simitar manner to the peer teview proctdure outlined in Section 3.3, with the following exseptions:

- the mock review will be bosed on the past pett review;

a the mock review will ixclude a session on how the estimate would be rated, and why; 
an executive summary will be created that will explain the original estimate, the peer review findings and the correotions tnade to date on the estimale packuge; and

o s plan for corrective measures will be deveioped, sobeduled, approved and madie available for the upconing review temo.

The documentation required for the mock review will differ from the peer review pnly slightly. Similar to the peer review, it will include:

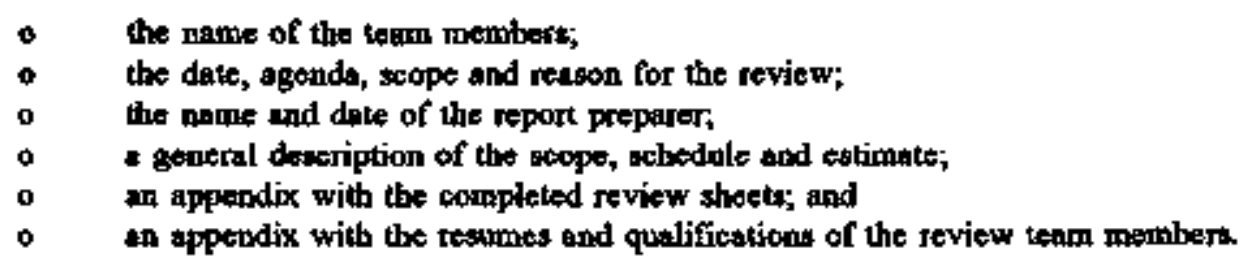

Rather than a section on rocommendations and findingt, the mosk review will list each reoommepdation with a plan, includiag sohedule and responsibilitios, for correstion of eacb finding. This is based on the premise that, due to the uposming review, the time to complete these tasks prior to review will be limited. Agein, by showing a corrective action plan, the negative findings on the real revietw cen be minimized.

\section{S.0 CHECK ESTIMATES}

A check estinate differs radically from the normal extimate review process beciuse a second estimato is prepered and compared to the original estimate. This is time consuming, but often worth the effort sipce a eomparative basis adds to the oredibility of the original estimnte. The chocklist (Appendix A) is not used - a seporato estimate is prepared following the procedures in the TWRS Cost Estivatimg Stavdands and Practicess Guide.

\subsection{Defínition}

From DOE Order $5700.2 \mathrm{D}$, a check estimate it:

"a valjdating estimate. Its developnent and use is similas to an independent oost estimate, exsegt it is developed by program/project or DOE Field Oftroe persomet or their supperting contractor. A check estijnite should be developed by someone who had no iavolvement in the original estimale, but who may be af advocate of the project."

\section{$5.2 \quad$ Purpose}

The primary purpose of the theck estimate is to validate the reaconableaces, completeness and somsigtency of the original emimate. It also serves to oorroborte assumptions and scope interptetation since both estimates are prepared from the same scope. Weaknesses in the seope dooumentation, schedule logis and cast estimate can be jocsted by this direct omparison.

\subsection{Procedure}

Following standard estimating methodologies, prepere a cost estimate and scbedule separate from the originel 
ostimate for the program element or projest. Use the strute scope, assumptions and WBS to provide a framework for comparison of similat activities. Ensure that the extimate is consistent with DOE Order 57002D and in accordance with FAR 15.804, "Cost and Price Data Analysis", as applicable.

To choose a conect estimate methodology, refer to the THRS Cast Emmation Manual, Cost Estimating Standards and Practices. Once the estimate is complete, a corpparison will be made at the astivity lavel for exch stivity abown in boub ostimates. Any activity with a $+\% 10 \%$ deviation in labor hours or total cost shoukd be explained and documented. A reconcitintion report will ghow the two estimates and the final, "go forward" oslimate that may include parts from each (the original and obock egtimate).

\subsection{Doctumentation Requirements}

The priranry documents that are required are the oomplete cheok estimate and the feconciliation report. The complete estimate shall inchude all the estimate work sheets, gtrmmiry theets, scope, soliedale and back-up documentation necessary to provide an activity by activity comparison of the estimales.

The roconciliation report shall have two sections. The executive surponary shall contain the plannod disposition of the estimate and oxplain bow the finel number was achieved. The appendix will contain an activity by ectivity compurison of the two estimates, and variance reports for those outside the activity thresholds (see 5.3). This report stall remain with the extimate file for futnure reference.

\section{0}

\section{BENCHMARKING}

In increating use of an artalytical tool in privale industry, benchmarking in a way to verify the planing of a diserete activity or product, and using that-comparison to arive at the best posaible plent. As an exampile, TWRS mby wish to compare an activity such as tank maintersance to threc or four other private finms or governmentel agencies and see if productivity, materials, and other costs art in line with the TWRS predicted costs (estimates).

Not all activities within TWRS can be benchmurked due to the researah nature and first-of +t-kind tochumologives employed in some of the activities within TWRS. For those activities that cen, benchnarking is a powerful tool for picking up the best mothods used in industry, and checking productivity at the same time. Most neviewers see benchmarking as s very solid lechnique for program justification, although it should be conducted as part of an overall peer review program.

\section{6.] Definition}

Borrowed from the glossary of land sarveying, a benchmark is a point of reference, olearly delineated so that mesaburements cas be taken from that point of reference. As it applies to the TWRS Baseline, the verb "benchnsarking" is the octivity of supplying a point of teference to the program from an external source so that the TWRS extinate is compared and valideted.

\subsection{Purpose}

The purpose of a benchmarking exercise is twofold. First, by looking at other practices and procedurts in industry. it is possible to "glean" the best methods and practioes for that activity within TWRS. This leads to s more cost effective, modern progrem. Second, the reasonableness of each activity cten be verified. If four other industries produce the same servioe for easentially the same cost, and the TWRS activity is $50 \%$ higher, that 
activity will noed further research. It my be that the additione] costs are justified If, all things being equnl, the TWRS entivity is the same es the compared activitier except for sompliance to a DOE Oder, it may be that the additional costs are tue to compliance to that order, and po estimate modifications are required.

In any ense, this self-assessunept tesknjique wlows TWRS to take a proketive management posture and streamline the TWRS Program.

\subsection{Procedure}

The procedure, in order, thet must be followed to produce a benchmark analysis is:

- to select an appropriate activity to benchmark:

- to decide on parameters that should be eompared (e.g., labor hours vs. labor hours);

o to research firms other laboratories or other sgencies that also perforn that activity at about the same scale tat scope;

o to vixit these foefitities that would sllow the study; and

- document and record the parameters from a benobmatk checklist, and prepare a benchmark anciysis seport.

In preparing the estimate, benchmarking follows the allowable "specific apalogy technique". The estimate is tovelojed, and adjustments are mode to known costs to account for differencet in relotivo complexities of performanos, desiga, and operational charecteristics.

It is importent to reoognize that cost vs. cost tnay not be an eccurate pieture of two operations. The overhead, contingency, tabor rates ood other factors will infuenee a summery cost osmparisoo. The proferted method is to compare labor hours to tebor hours, material unit costs, percentages of training time, impoet of safety sequireinents, and other messurable quantities.

An appropriate activity may be standard surveillance, seourity, sanugling, anslysis, sitte maintenance, filter replectement, monitor well devekpment, and so on. Remember that comparisons should be made as olose to TWRS scope as possible. The development of a monitoring well, for instance, should compere the same type of well, dug for similer purpose to roughly the same depth, and in very similar geological strata.

\subsection{Documentation Requiremeats}

The benchmork checklist is a tool to document the actial or extimated costs for the similar activity being benohmerked. The key is to use the same checklist from site to site so thet direat comparisons are mede. For instance, if a comparison is mede on bastel purchase $\alpha$ ssts, the cost (diecount) nay be affected by the quantities purchased by that industry in a given time period. The checklist sbould capture the "quantity purchesed" dato as part of the head-to-head compariasn.

Due to the specitic nature of ench activity being benctmanked, development of ose master checklist is not

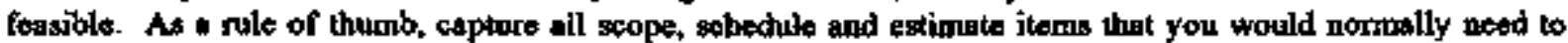
prepare a detailed cost estimnte, and you will heve the correct dath elements that you need to capture in the benohmark exercise.

The second part of the report should contain the analysis of the dita gathered, findings and recommendations. This documens thould include an action plan, if necessary, besed on the results of the findings. It should also be kept with the eatimate for future reference. 
[Per phene conversation t/27/93, Lon M. to provide detall or will be palled together in Rishlend in Febrianyl

\section{g.O REVIEW PERFORMANCE CRITERJA}

The conduct of any reviow must be based on accepted and understood performance opiteris. The following criteria sonteined in Appendix A, TWRS Master Checklist, is a sypopsis of:

- The EM-30 Validstion Guidolines (used in FY 1992)

o The EM-30 Validation Guidelines (planned for FY 1993)

- Tho EM-30 Cost and Schedule Estimating Guide, Working Draft, Appendix F.

- FY 1995 Project Reviow/Valickation Criteria (PR-241, November 19, 1992)

This eriteria describes the acceptzble level of docunnentation, performance, and content of the scope, scheduls and coet elements of the TWRS Progrem. 


\section{APPENDIX A}

TWRS MASTER CHECKLIST

ADs Number:

WBS Number:

Program Name:

Program Looation:

Program Manager:

Review Date:

Review Location:

Reviewer"s Names

\& Organizations:

Review Type:

(circle one)

\section{Peer Review}

Mock Review 


\section{A. Finglats}

I. Has the aite waste management mission been defiped and summarized in the Ptanning Documentation?

Comments:

2. Is the planning methodology used to develop the program definition described in the Planning Documentstion?

Comments:

3. Are the major elestents of the program delitied and consistent with overall site mission and program goals?

Comments:

4. Has the DOE EM prograptratic end contractor WBS appliemble to the program been identified? Conunents:

5. Does the WBS conform the EM-30 approved WBS, and show each ADS and TDD? Corroents:

6. Is the level of detail of the DOE programanatio and contractor WBS Dictionary and WBS Index in the documentation for the program sufficient to allow a seview of specific broads-level ejements of the program? Comments:

7. Does the Master Schedule show the ADS and TDD activities within the context of an overall TWRS Program? Comments: 
8. Does the Master Schedule contain DOE HQ conitrolled milestones?

Comments:

9. Does the Master Schedule eontain DOE Fie]d Office controlled milestones?

Commenis:

10. Has a Responsibility Assignment Matrix (RAM) been developed based on the DOE EM programmatic and contractor WBS and organizational structure for the prograsu identified during the plannitrig process?

Comments:

11. Has a Document Hierarchy been developed for the program?

Comments:

12. Have document control procediures been devetoped and implemented?

Comments:

13. Are plannigs change control documentation and planning and programming bistory dooumentation available for reviev? Conntusts:

14. Does the ADS completely identify all legal drivers (title, seution, para.)?

Comments: 
15. Have tegulatory drivers and constraints and other internal and exiernal drivers and consuraints relevant to the work to be performed been identified and included in the Planning Doctmentation?

Comments:

\section{B. Texhnkell soans}

1. Is the scope of the estimate consistent with an overall installation Mission Plan. Operations Plen, of similar technicsl baseline document?

Comrsents:

2. The scope of the estimate is:

A. Highly speculative.

B. Moderately speculative.

Comments:

3. Identify basis of scope ( $\mathrm{P}=$ Primery; $\mathrm{S}=$

Sccondary)

A. Historical practices/related site experience(s).

B. Best engipeering/professional judgement (no reteted site experience).

c. State/EPAIDOE appoved complinnce agreement(s).

D. Applicable envircamental tegistation

(CERCLA, RCRA, CAA, otc.).

E. Inlernal DOE Mission siatemont or directive.

Comments: 
4. Has a complete Technicel Scope Documentation, including the following olements, been puepared for the program?

Description of the wark to be performed;

End condition or and product of work;

Perfomance criteria apd requírements:

Dismrete taskg and deliverables:

Resource requirements;

Sequence of events and discrete milestones;

Porformance methodology and task plans; and

Work not included in the scope.

Compments:

3. Ave the major asspunptions used in developing the technioal scope for the program clearly identified and justified in the Techniseal Scope Documentation? Comments:

6. Aue Tochnical Logic Diagrams and/or Process Flow Diegrams, where appropriate, included in the Technical Scope Documentalion?

Costments:

7. Have Milestone Log and Milestone Description Sheets boen developed that contain descriptions of each milestone associated with the program?

Comments:

8. Is the rotionale used to develop task oescriptions and logic diagrems, milestones, and resource requirements explained in the Technical Scope Documentation? Conments: 
9. Doss the Technical Scope Dacumentation for the program include specific activities ussocialed with the work to be performed and activity-based resource descriptions? Comments:

10. Hes en Activity Dictionary been developed for the program, including detailed descriptions of actjvitiess associeted with the work to be performed?

Comments:

II. Does the Teebrical Scope Dooumentation for the program inolude descriptions of support activities (e.g., occupational health and safety, quality assurance, security, etc.) assoeiated with the work to be performed?

Comments:

12. Are buck-up documentation (sucb as production or waste monagement plans, procoss technical and trigineoring data, process output ot throughpet projections, and historical opetating dala) ayailable for teview, used in scope development, and referenced in the Technical Scope Documentation?

Comments:

13. Is the technical scope for the program consistent with the site mission, regulatory drivers and constraints, and internal and extemat drivers and constraints (ef, consent onders. permit condítions. regulations, orders, etc.) identified during the pinaning process?

Comment: 


\section{Cegat Kationte}

1. When was the current cost estingate prepared? Comments:

2. Has the estimate been revised'updoled? Why? Comments:

3. Was the cost estimate independenlly poer reviewed by the MaO contractor? What documentation exists? What methodokgy was used? When?

Comments:

4. How would you characterize the maturity of the estirrale? Comments:

5. Is the estimate detoil commensurate with the level of requested funding?

Comments:

6. Are hiakorical cost data included in the Dost estimate for the activities for which oosts bave been estimated?

Comments

7. Do the bistorical data used to prepare the cost estimate show each activity costed and show the cost of conciucting that activity, broken down into the quantity associated with eact activity and the labor cost. material cost, and other costs incured per unit quentity?

Comments: 
8. Are indirest, overhead, or other costs that are distributed nong activities included in the cost estimate olearly and individually identified?

Comments:

9. Are direct oosts that are associaled with individual activities included in the eost ostimate clearly and individually identifjed? Comments:

10. Are the indirect labor costs used throughout the cost extimate approved and rudited, and appropriately and correctly identified? Conments:

11. Are unit labor costs broken down inlo direct costs and indirect costs?

Comments:

12. Has the cost estimate been updeted in a timely menner in response to relevant changes in its basis, background data, or assumptions?

Comments:

13. Are an appropriate Change Control Document and an Estimate Development History attached to the cost estimate? Comments: 
14. Doss the Estimate Development History incluot an itemizes and chronological list of the changes made to the cost estimate sinoe initiation of its preparation, and the rationale for each change?

Comments:

15. Is an Estimate Purpose Statement included in the cost estimate? Does the Estimate Purpose Statement elearly describe the parpose of the estimate?

Commonts:

16. Is the scope of work for the program for which the cost estirnate was prepared adequately desoribed and ponsistent with the planning and Technical Soope Docurnentation developed through the planning and scoping process?

Comments:

17. Has an estimate-specific Work Breakdown Structure beed developed for the ptogram? Comments:

18. Does the estimate format follow the WBS? Comunents:

19. Does the estimate-specific WBS organize the work to be performed in a logical and potisistent manner?

Comments: 
20. Were activity based costing (ABC) methoda used? If not, briofly deseribe the estimating mothod

Comments:

21. Are sotivities, quantitíes, and unit costs associated with the work to be performed elearly identified and defined in the cost extimate?

Comments:

22. Has on estimatc-specific Activity Dictionary been developed for the program?

Comments:

23. Does the estimnte-specilic Activity Dictionary describe all activities associated with the work to be performed in a logical end consistent manner? Comments:

24. Are the assumptions and exolustions upon which the cost estimate is based clearly idemififed and defined in the cost estimate?

Comments:

25. Aro time and cost assumptions and cost elements associated with each activity clearly identified, defined, and documented in the cost estimate? Cost elements for program activities include:

Qunntity;

Unit of measure;

Lubor bours per unit;

Total labor hours; 
25. (Continued)

Material usage rate per unit:

Total material eost;

Equipment usage rate per unit;

Total equipment cost;

Overbead rale; and

Total overhead allocated cost.

Comments:

26. Indicate which of the following wete documented as part of the estimating besis:

A. Capacity/sizing of systems/cornponents.

B. Regulatory uncertainty.

C. High cost growth areas (lobor, etc).

D. Trajning.

E. Conduct of Operations.

F. Quality Assurance.

G. Mission changes.

H. Funds availability.

I. Funds carcyover.

J. Resource availability.

$K$. Infrestrunture considerotions (WIPP, elc.).

Comments:

27. Are significant findings of the cost estimate preparer identified during preparation of the cost estimate included in the cost estimate?

Comments:

28. Have estimate factors been used to adjust the cost estimate? If so, have they been. odequately documented and appropriately applied?

Comments: 
29. Have eacolation faotors been ased to escalate the sost estimate?

Comments:

30. If escalation factors provided by DOE

Headquarters bave been used, have they been adequately dacumented and appropriately applied?

Comments:

31. If excalation rates other than those provided ty DOE Headquarters have been used, have they been audited and approved by DOE Headquarters?

Comunents:

32. Dexcribe how contingency was caleulated and managed.

Comments:

33. Was contingency applied to operating expense (non-construction) dollars? Comments:

34. Are indirect rates used in the cost estimate adequarely documented and appropriaiely applied?

Comments:

35. Are Estimale Summary and Detailed Reports included in the cost estimate? Comments: 
36. Do the Estimate Summary and Detajled Reperts provide cost totals for each activity in the Activity Dictionery and for each oost element in the oost estimate? Comments:

37. Is a schedule included with the cost estimate? Comments:

38. Are aotivities inaluded in the schedule consistent with those jncluded in the Technical Scope Documentation, Activity Dictionary, and cost estimate? Conments:

39. Aro milestones and deliverables ineluded in the sehedule eonsistent with those included in the Technisal Scope Documentation and cost estimate?

Comments:

40. Does the funding protile conrespond to the timing evident in the sobechule? Comments:

41. Are areas of cost and schedule risk identified in the estinate? Cormments:

42. Is an Estimate Criteria Dooument included in the oost estimate?

Comments: 
43. Does the Estimate Criteria Document clearly describe the methodology by which the cost ostimate was developed? Comments:

44. Does the Estimate Criteria Docrment clearly desscribe the basjs for the cost estimnte and the sssumptions made in developing the cost estimate?

Comments:

45. Hes the entire cost estimate paokage (ineluding teohnical soope and schedule) for the program been subject to peer review by individuals who were pot involved in preparation of the oost estimate, but who are qualified to have prepared the cost estimate themselves?

Comunents;

46. Has the peer review considered the elements Jisted below?

The basis for the assumptions mode in developing the cost estimate;

Consistenoy of assumptions rode in the

cost ostimate, technical scope, and scheduls;

Consistency of definitions of activities

in the cost estimate, technisal scope, snd schedule;

Congistenoy of durations of activities

in the cost estimate, technical scope. and schednle;

Documenlation of productivity and unit cost data for program activities; and Appropriate use of indireet rates, essalation factors, and other factors used by the cost estimate preparet.

Comments: 
47. Have the document findings and recommendations of the pere review been documented in a Peer Review Document? Comments:

48. Is the Peor Roviow Document ixcluded with the cost estimate oocumentation? Comments:

49. Heve the findings and recommendations of the peer review been addressed in revisions to the cost estimate?

Comments:

50. Are sctivities included in the schedule consistent with those included in the Technicel Scope Documentation, Activity Diotionary, and cost estimate?

Comments:

51. Could an independent cosi ostimale be prepared based on information contained oc referenced in the sstimate?

Comments:

52. Are appropriate comptuter software packages employed in estimating the program? Comment: 
1. Was a network logio diagram prepared fot the estimate?

Comments:

2. Is the level of detail is the schedale adequate to separato dissimilar activities and divide the work effort into quantifiable elements? Comments:

3. Are intemal or extemal constraints outside the manager's control (e.8. issersnce of a penmit, award of a contract, start-up or shut-down of a releted facility) identified principolly in the planning and sooping process, described in the Technical scope Documentation, and recognized in the schedule?

Comments:

4. Have the following factors been considered in developing the program schedule? Milesione Log and Milestone Deseciption Sheets; Milestone responsibilities (program, contractor);

Budget cycle timing and funding sources;

Contractor selection process and selection duration;

Regulatory drivers and other internal and external constraints: DOE Field Offec, DOE HeBdquarters, and external review schedule;

Pterequisite technology restarch and development constraints; Required training and certifications; and Operational constraints. Comments: 
5. Are top-level milestones traceable down to lower level sechedules?

Comments:

6. Indiaste which of the following detrils have corresponding sohedule aclivitics or milestones:

A. Long Lead Procurement.

B. Trajaing.

C. Field Office and Headquarters Reviews.

D. Regulatory Docurpentation.

E. Mission Plan Approvil.

Comments:

7. Are the durations allowed for each activity reasonable, justifiable, and consistent with the progran technical scope and cost estimate, allowing each schodule duration to be documented from rocords ond studies maintained at the site?

Comments:

8. If a facility is operated by a contractoz other than the on-site $\mathrm{M} \% O$ contrastor, is sufficient time allowed in the ochedule for the procurement action lo bring thal contractor's work force on to the site and establish site operations?

Comments:

9. Are epproprinte operator training cycles incorporated into the schedule for the program?

Comments: 
10. Does the schedule talte inlo account uny operational cosstraints, including restricted working hours, petmil conditions, programined shut-down or stast-up, that may influence the schedule?

Comments:

11. Is it possible to document each schedule duration from records and studies maintained at the site?

Cormututs:

12. Has the sohedule been cesouroe-loaded? Comments:

13. Does the sehedule contain the same resoures description and allocations that are in the estimate?

Comments:

14. Estimate the percentage of schedule activities falling into the following categories:

A. Level-of-Effort entire year.

B. Lovel-of-Effert less than an entire year.

C. Discrete activities; no milestones.

D. Discrete activities; milestones.

Cominculs:

15. Applicable DOE Ordors:

Do the schedule sequoncing and timing of the program correlate to the planning. teporting. documentation and review criteria of DOE 4700.] (Project 
15. (Continued)

Maragement Systent) DOE $\$ 100.5$ (Office of

Management and Budget--Budget Proctess), and DOE 5100.3 (Field Budget Process), as applicable?

Does the schedule incorporate etements for epplication to DOE 1332. IA (Uniform

Reporting System)?

Does the schedule meet resource, doetuntentation, and reporting requirements of DOE N4700.5 (Project Coutrol System Guidelines)?

Comments:

16. Is manegement commiturent to the scheduling prooess ovident?

Commonts:

17. Are appropriate computer sofware packages employed in schedaling the program?

Comments:

18. Is the level of detail of the schedule appropriate consideting the maturity of the program?

Commonts: 


\section{Project Validation Checklist - TWRS Project Checklists}

The following questions are applicable for projects under the TWRS Program All nom-capital estimates do nor repuire screening through the following criteria (adapted from sthchment 4, PR-24l FY 1995 Ptoject Review/Nalidation Guidance). 


\section{SCOPE}

\section{A. General}

I. Where necessary, bss agreement been reached between the program division. field office, and/or operating contractor on the facility operating (performance) requirements?

2. Are focility requirements defined in terms of real propenty requirements, process defunition, artangement. system layout, operations, maintenance, utility supply. distribution, and cost?

3a. Has DOE Order 6430.1A, GENERAL DESION CRITERIA, been used in developing the Conceptual Design Report (CDR)?

3b. For areas pot covered by DOE Onder 6430. LA, what criteria are used?

3c. Hes the intention to conduct a DOE 6430.1 A compliance analysas and review been expressed? (Required per DOE Order 5481. IB, Safety Analysis \& Review System).

4. Have sufeguands and security requírements been considered in the development of the CDR? Have they been reviewed and accepted by safeguard and security personnel, and are they in sccordance with the latest Master Safoguards and Security Agreement?

5. A site pian(s) of the project shall be forwarded for review by the validstorIs the project location predeternined by existing facilities or is site selection recessary? What is the basis for the site selection and what allerastives wore considered? Is the project site shown on the current approved baseline Five-Year Ples from the Technical Site Infortation as described in DOE Order 4320.18 of $1.7+91$, SITE DEVELOPMENT PLANNING? If not, hes 


\section{5. (Contínued)}

an Engineering Control Change to the baseline Five-Year Plan been completed, approved by the Departsnent of Energy (DOE) Field Offrese, and distributed to Headquerters? If land acquisition is required, hes the implementation of DOE Order 4300.1, REAL PROPERTY AND SITE DEVELOPMENT PLANNING been iritialed?

6. Are functions of structures, systems, and intojor compononts definedi Heve volue engineering lechniques been utilized to analyze these functions.

7. Has the procurement strategy bees coordinated with Headquarters Procutement Operations stam?

8. Have facility demsnds been matebed with site utilities, roads and support facilities? Will utilities, roads andy or support facilities resuire futare opgrades/modifications to malch infrastructure demand?

9. Hove requirements for initial complement of equipment been defimed?

10. Are quelity lovels and progrem requirements established?

11. With present ksowledge of the proposed faoility, can emissions and wastes be treated or dispored of in coctiplinince with Federal and Stato stondards?

12. Have State, locat or nationsal codes and standerds applicable to the work and operation of the facility been defined; oan the fovility operate within these codes and standards?

13. Does facility provide office space for operating staff and does the amount of space conform to guidelines issued by General Strvicos Administration? 
14. Are space requirements in addition to cursent space aveilable, or is it replacement for substandard space? What is the tisposition of the building/space being replaced, demolished, converted, etc.?

15. Do projects meet the SEN-15-90,

NATIONAL ENYIRONMENTAL POLICY ACT

requirenents, or have Environmental Assessment (EA), Epvironmental Impact

Statentent (EIS) or Categorica]

Exclusions been prepared, as required by the Assistant Secretary for Eavirodutem, Safely and Health?

16. Have the requirements beon nat for onsuring that new DOE facilitits demonstrate now or emerging energy effioient technologies as presented in DOE Notice 4330.3, ENERGY EFFICIENCY.

17. Have Construction Project Data Sheets been submitted for "Operation Expense Funded" projects over $\$ 1.5$ million and, in porticular, those that ter listed as Mejot System Acquisitions?

B. Deaga (Cenceptual, Title I, Title It)

1. What is the status of the design? The engineering must be developed to the poimt of establishing initial scope, cost, and scbedulie basejines at CDR. The following should be included as part of the design docunents:

- site development plans including utilities

- building layouts

- major equjprent atrangement

- piping and instrumentation diagrams

- process and heating, ventilating, and air-onditioning layouts

- electrical single-line diagrams 
1. (Continued)

- major mechanical, electrical, and experinental equipanent list with sizing and codes, standards,

Quality Assurance (QA), and other principal special provisions

- most reasomable utility supply option selected

- utility requicements impacts; availability of outside sources; the most reasonable utility supply option seloctod

- DOE 6430. IA compliance analyses and revicw

2. Have there been any soope changes since the last validation? If so, have ratjonale, oost and schedule impact been identified?

3. Are site oontition: understood (c.B. legal enoumbranoes and restrictions. soil borings, water table, borrow and spoil areas, railroad bridge and road acoess, utility scurces and routing restrictions, constrution site layout and limitations)?

4. Have safety hazards and risks been determined and have appropriate safety evaluations been performed?

5. Has the design andergone a value esginecring study, and if so, have design slternatives been inoorporated which are life-cyole oost effective?

6. Has an environmental essessment been performed? What is the slatus of environmental doctimentetion?

7. Has Restarch and Development (R\&D) prerequisite to facility design and construction been identified, scoped. scheduled and funded? 
8. Have all those who could influence the design participated in development preparation and approvel of the concepi?

9. What are mejor arees of uncerteinty (e.g., R\&D, design feasibility, schedule, elc.) f Hes this been factored into the risk astessment to delermine the contingeney?

10. Has the Energy Conservation Report as required by DOE Order 6430. IA been prepared as a part of the design?

11. For applicable buildings, or building areas, does design meet Title 10, Code of Federal Reguletion Part 435, Energy Conservation Voluntary Performance Standards for Commercial and MultiFamily High Rise Residential Buildings, mandatory for new Foderal Buildings?

12. Have mointainability considerations been built into the design, and does the design contain a good mainteinability checklist specifically oriented to this project? The maintoinability concerns that should be addressed are:

- accessibility

- operator/user friendly

- documentation

- standardization/interchangeability

- flexibility

- desirable levels of quality 
I. Have the following factors been

considered in developing the scheduje?

- effects of weather ind season

- ressurce loading and leveling

- miliestope responsibilities (AE, program, project, contractor)

- budget cycle timing

- contractor selection dunations

- Headquarlers revitws and approvals (inchuding NEPA and Safoty)

- prerequisite R\&D schedule constraints

- dependency upon tining and amount of operating fundts

- hislorical experience on design, procurement, construction, techoicel reviews, National Envirommental Policy Act documentation, etc.

- development of euvironmental documentation

- procurentent lead times for equipment (particulerly refleoting vendor quotes)

- logical sequence of design, procurememt, and construction

- realistic obligation and costing rates

- workplace space constraints

- exposure constraints

- operational cotatraints

- moinlainability roviews and deliverables

- milestonte dictionary

\section{Cout Eatimate}

Details provided should be consistent with complexity, scope nature (iirst-of-a-kind v8. repetitive), and status of the dosign (conceptial. Title LII, etc.). Cost estinates and surmaries should be understandtable and be provided in a single volume if possible. Compulerized CS2 reports are not acceptuble. Provide assumptions, basis of the estinate and narrative as required to furrish complete explangtions. For major technical projects, the following estimuting practices are pertinent: 


\section{A. Geweral}

1. When was extimate prepered? Are estimates provided in beth base year ond then year dollars?

2. Basis of estimale: vendor quotes, similar projects, engintering calculations, elc.

3. Are estimates traceable and supportable, where necessary, with vendor quotes?

4. Do oontingency and escalation refleot the guidapce issutd (Cost Eslimating Guide for Application of Contingency, Note Contingency Guidelioe Implementation, paragraph 5.b)? Does contingency reflext level of confidence in scope of work, development features, pricing methodology and complexity of project Does contingency analysis provide for varying degrees of certainty in the eatimate?

5. What escalation rates are being used? Whet documentation or enely sis was used to support these assumptions? Have they been included and applied in a logical and consistent mannec? What changes in estimates have occurred as a result of changes in escalation assumplions used in previous estimates? Hove program. related changes been identified and erosswalked (schedule, technical, scope, or economic condition)? 
6. Have there been independent reviews of the project estimate? When was the estimate updacod? How whs the estionate updated? (i.e., trends "bottoms-up," only obanged work, eto.). When was the last "bottoms-up" estimate performed?

7. Whete unigue construction or fabrication practices are required, has pricing advioe been obtained from experienced tisnis knowledgeable in the field?

8. Where attempts are made to use ostimating guides based on conventions] construation items, have they been properly interpreted with recquired geogrophic, quantity, and complexity adjustonents?

9. Are indirect costs, profit, fees, tec., included? Are teasonable rates used? Have these been audited?

10. In the case of Title $\mathrm{I} / \mathrm{I}$ design estimhate, were all the specifications and drawings evailoble for development of the cost estimatef

11. Are all required experinental components included in estimate?

Has a procurement stralegy been developed, i.e., Government Furnished Equipment, Cost Sharing, Cost-PlusFixed-Fee, Cost-Plus-Award-Fee, etc., for contracts and major cost items?

13. Are materials and systems selections, espesially to they ootoern gneintainability, based on life aycle costs zather than first cosis identitied?

14. Have Total Estimated Cost and Tolal Project Cost definitions been properly applied? Do the estimates refleot proper tinancial management practions and procedures? 
B. Conatruction

1. Were bulk malorial quantities, established by takeoffs from conceptusl drawings, besed on engineering estimates or factored from previous work?

2. Are allowances fot quantity growth reoded or provided?

3. lo bulk maloriel pricing current and reflecting local conditions where appropriate?

4. Is labor estimaled using local rates, including applicable fringe benefits, trovel allowance, and reasonabio crew or creft mix? Was the availability of construction labor sritical skil] categories in the local labor market considered?

5. Is pricing of equipment supported by current vendor quotes or recent actual expositence?

6. Heve indirect construclion costs been ineluded for normal support, field engineering, temprorary construction, mobilization, warehousing, elc.?

7. Is labor productivity based on historical experience adjusted or appropriate for site or unusual facility foatures?

8. If labor availability would be a problem, have allowances been included for attricting adequate work force? Have construction of clessified projects been adoressed relative to ckensed wotk force?

9. Does pricing reflect code, $Q A$. scbeduling, olimatio, geographic, and othes unique specification requirements? 
10. If unitized prioing hes been spplied, are the raw material and labor cost, equations and other backup data provided or available?

11. Are operational cost estimates and basis for overhead cost included and explained?

12. Has a transition plas from construction to operations been developed along with procedures for controlting costs?

\section{Eagineeding and Manageosent}

1. Do the Engineering, Design, and Inspection (ED\&I) Costs follow the guidance. The Defirition and Treatment of Engineering, Design, and lnspection Costs, August 23, 19857

2. Are contraetor project management and engineering costs appropriately churgeable to the project included?

3. Was EDRF built up by assessment of drawings, specifteations, analysis, comparable experience, ot a percentage of construction?

4. Are Title III inspection, QA and Quality Conirol costs included for Architeot Engineer, operator and oonstruction, as sppropriate?

5. Is the management system organized and planned reasonable and responsive to project/progrann needs? Is authority at the proper levels? Are there duplicative or overlapping responsibjlities? Is a cost and schedule deviation evaluation system in place? 
6. Is an effective baseline change control system in place including board charters and responsibilities? Are project baselines change procedures and process deftued and understood?

\section{rV. Funding and Cost States}

1. What is the busis for the planned authorization, appropriation, and costing schedule? What alternativos were considered?

2. What are the other essociated project costs?

3. Is the proposed annupl funding consistent with a realislic project cchedule? Is it based on an evaluation of planned contract awerds delivery lead times, and logical criticat path activity sequepeing?

4. Have alteraalivos beon considered in the event of a Continuing Resolution or seduced funding? Impects?

5. Are any of the fixed-pxice construction contracts in the project incrementally funded?

6. Has the funding by client or oogsultant agencies been identífied?

7. Have eny reductions in project funding or funding requests ressilted in the elimingtion or reduction of energy conservalion of maintainability items? 
U.S. Department of Energy DOE Hanford Reservation

\section{Tank Waste Remediation System}

(TWRS)

\section{COST ESTIMATION MANUAL}

- Cost Estimating Standards and Practices -

Draft 1.0

Jantary, 1993 
WESTINGHOUSE HANFORD COMPANY

TWRS COST ESTIMATION MANUAL
Manual

Section

Page

Effective Date

Organization
WHC-CM-X-X

$\mathrm{XX}, \mathrm{REV} \mathrm{X}$

1 of 9

1/19/93

Level 1 acro/Loved 2 org
TETLE:

COST ESTIMATING STANDARDS AND PRACTICES
Approved by

XXXX, Manager

$\mathrm{XXXX}$

\subsection{PURPOSE}

The activities associated with the Tank Waste Remedietion System (TWRS) at Hanford inelude both project and program offorts that are large and comptex. Plasining at TWRS is a ohaflenging task; risk areas such as regulations, teshnologies, management practices, othot rocuinomonts and uncerteintice art an integral pert of TWRS. The parpose of this guide is to delineate the estimating activities required for TWRS planting abd to east implementation of the recently pronulgated Office of Waste Management (EM-30) Cost and Schedule Estionating Guide as it applies to the TWRS Progrem.

The ultimale purpose of this manual is to supply the necessary direction to prepare defensible, credible TWRS cost estimbtes. These estimates can then undergo review sonutiny, be rolled up to feed the bodget process, and survive to form the basis of a histotical record for TWRS ohanges and decisions.

\subsection{Intendad Audience}

TWRS Division, under the management of the U.S. Dopartuent of Energy - Richland (DOE-RL), is authorized af a work activity conducted by Westinghouse Henford Company. This guide is to be used by TWRS and/or their associsted subcontractors as a wotking document and estimate preparation referenee.

Estimators, schedulers, Cost Account Managers (CAMs), program element and program managers, and program reviewers will find the TWRS Cost Estimating Manual to be a practical managenent reference tool. The list of users ipcludes anyone who (1) prepares TWRS cost tstimales, (2) validates the estimates and the estimating process, (3) reports the estimates to the customer(s) such as DOE-RL and DOE-HQ, (4) measures actual cost and schedule progreas againat the eatimates, or (5) provides ideas into future revisions of the process.

\subsection{Future Development of the Guide}

Throughout this document, reference is made to historioal costs and historicas estimnte basis as a preferred supply of estimate data. This original oost guide, while incorporating the innovative techniques of Activity Based Cosaing (ABC), does little for providing a sound bistorical basis for costs. A major revision will inclute:

- a bistorical oost gathering prooedure;

- TWRS activity diotionary (code of accounts);

- validated cost estirsating relationships (CERs);

- activity tracking on repetitive scope (e.g., Conceptual Design Report); and

- a method for doctmenting, publishing and revising the TWRS Unit Cost Book. 
The benefits of initiating complete estimates aze both short and long term. Initially, the process of an activity by activity look at the TWRS Program will result in better ptanning and decision making by both the contractor and DOE. Increased likelihood of progrerumatic funding and budget approval is a positive ontcome of higber quality estimates. Long term, the benefits of beiter program manigemenl and performance measurement as well as the collection and use of historical cost data will substantially impove the overall TWRS program

\subsection{Local Cost Gujde Criteria}

This guide conforms to the local cost guide criteria set forth in DOE Order $5700.2 \mathrm{D}$, attachment 2 . with the following exceptions:

Section e., cost codes of account, will be added since sufficient reasons exist for development of local cost codes of account (activity dictionary);

o Section $f$, contingency, is defined and diseussed, but a procedtre for conlingency analysis is missing; and

0

Section $k$., collecting actuat cost data, is only briofly zddressed.

\subsection{SCOPE - COST ESTIMATE BASELINES}

The Jaission of the TWRS Division Charter (Septemher 3, 1992) is to "manage plants and facilities costeffeotively and in compliane with applionble nuclear facility operating standards". The key to oost-effective management is cost effective, comprehensive planning. The monagement of TWRS has chosen the baseline concept as the tool to meet the demands of this charter.

Any activity, eilher program (non-capital) or project (capital) based in the TWRS Program, reguires a series of cost estimiates with associated scopes and schedules throughout the life of the program or project. On a fundamental level, remember that on estimate is just that; en estimate. The activity of predicting future events and assooiated costs and sehedules is both an art and a science. The better estimates are besod on betier predictions. Prediction is based on the ability to assimilate history. experience and judgment in a format that is easy to express and understand. Although estimating concepts and methods are not new to those familiar with projects, the applicalion of estimates to non-capital cperations is new. As a non-ciepital estimating melhodology, the Office of Waste Management (EM-so) Cost and Schedule Estimating Guide discusses the idea of Activity Based Costing (ABC) in detail. This concept, introduced in Novesnber, 1991 by EM-30, uses cornnon ostimaling techniques and methods borrowed from the construction industry and applies those to operations. For example, one of the first planuing activities is to develop a Work Breakdown Structure (WBS) for the operalions activities to be execuned. Until recently, a WBS was not seen in the operations planning arena at a leve] conducive to cost estimation.

Il is essential that TWRS cost and schedule estimates be developed consistently using accepted methodologies. Each estimate should have a well-documeoled besis that identifies all krown program/project data and assumplions. It is recognized that many TWRS activities and operations are not yet fully defined and that definition will improve over time. However, known elements must be provided.

Estimates must be based on concepts, operations, andior designs that tre cost effective, even when the major paramelery and characteristics can only be sssumed It is understood that program concepts, operations, and designs will ovolve and that, consequently, cost estimgtes will become more firm. However, "plug ntubbers" or allowance amounts instead of cost estinstes are nol acceptable. Even if little is known about the soope, as oflen bsppens in the oul-years, alt assumptions are to be documented and the estimate developed to the greatest level of detail possible commensurate with the kevel of information available. 
A Baseline is a quantitative expression of projected costs, schedule, and technical requirements. Baselime establishment should include criteria to serve as a base or standerd for measurement during the performance of an effort. A baseline is also the data plan against which the status of resourees and the progress of a projest can be measured.

TWRS does not distinguish between program (expense) or project (capilal funded) octivities under the baseline concept. Any activity, including those conducted by DOE within the TWRS Progrsm, is subjeat to teohnioat scope, schedule, and cost senutiny.

\subsection{Near Teym Versus Out-Yoar Cost Estimates}

TWRS is faced with project and progran elements that require life cyole cast estimates that span deades. To conduct semsible planning, out-year estinates arc treated differently than pear tem estimates. The method chosen for an estimate will also depend on this crucial timing foctor - il doesn't make sense to do a "bottomsup" estimate on a TWRS activity scheduled for 2015. To establish this relationship. neet torm estimates and out-year estimstes are defined.

Near term estimales apply to ectivities forecssted for the next two operating years. This "window" on the total TWRS Program begins with the current execution year and "slides" one your out at a time to update the plans and estimates as time moves of. Because they are bused on ressonably accurate knowledige of the work to be accomplitshed, the estimator bas a relatively high degroe of confidence in the work seope, logio and schedule and is more willing to identify as many indjvidual oost eomponents as possible.

Near term estimates are based on (1) identification of the lowest possible level of individual cost components of a particular activity, (2) their quantities, and (3) their indjividual cosss. A TWRS Unit Price Book will be developed to help specifically in the near cerm estimating process by providing a sound "basis for extirnate" at the required component level.

Cost estimates for out-year activities are less detailed and more "scoping" in nature. Metbods such as Aotivity Besed Costing (ABC) are more difficult to epply here, elthough oome aspeots, like a program WBS, should still be developed. Out-year cost estimates contain less detail because (1) the work soope and schedule are fas less aeftsis and (2) the cost to perform that work is less certain due to potential chenges in legal or other reguiremenis. Out-year scoping estimates will nat generally include as much detailed backup information, but will be based on a combination of projected work scope and the near term cast estimates for similar work scope. Out-year cost estimates tely beavily on assumptions, especially in work seope. Assumed work scope must be olearly artieviated in ell planteing documonts in order for scoping estimstes to be of value. Remember, it is crueial that these assumptions are wefl articulated and documented. These out-year estimates will get revised; it is important to understand the original stope, schedule and cost thinking upon revisjon. At with near term extimates, estimators atc entouraged to seck opportunities for generating "ecomomies of acale" for projects or programs with many similar antjvities that are soheduled in parallel time frames.

\subsection{ESTIMATING METHODS}

As disoussed earlier in the peer temi versus oul-ycar estimating, the estimation method used is based on several faotors and on the basis of the estimate. Different methods are more dosirable al different times. Figure 1 illustrates the relationship between aceepted methods and the basis of the estimate. The trend is obvious; the nearer the term and the more defuritjve the basis, the arose likely that a full bottoms-up or ABC type estimate is required. Conversely, as shown in Figure 1, it does nol make senoe to force a preliminary estimate isto a definitive, boltoms-up approach if another method (e.g-, parametrio cosputer model) would produce results. 


\section{Estimating Methods Vs. Basis TWRS Program}

\begin{tabular}{|c|c|c|c|c|c|c|}
\hline \multirow[b]{2}{*}{$\begin{array}{l}\text { Estimating } \\
\text { Basis }\end{array}$} & \multicolumn{6}{|c|}{ Estimating Methods } \\
\hline & $\begin{array}{l}\text { ABC \& } \\
\text { Bottoms-Up }\end{array}$ & $\begin{array}{l}\text { Specific } \\
\text { Analogy }\end{array}$ & Parametric & $\begin{array}{l}\text { Cost Review } \\
\text { \& Update }\end{array}$ & $\begin{array}{l}\text { Trend } \\
\text { Analysis }\end{array}$ & $\begin{array}{l}\text { Expert } \\
\text { Opinion }\end{array}$ \\
\hline Planning/Feasibility Study & - & $\gamma$ & $\sqrt{ }$ & $\sqrt{ }$ & - & - \\
\hline Pre-Conceptual/Budget/CDR & - & $\sqrt{ }$ & $\sqrt{ }$ & $\sqrt{ }$ & - & $\boldsymbol{\bullet}$ \\
\hline Title I & $\sqrt{ }$ & - & $\square$ & • & & - \\
\hline Title II & $\sqrt{ }$ & - & $\bullet$ & & & • \\
\hline Government/Engineers' & $\sqrt{ }$ & & & & & \\
\hline Current Working Estimate & $\sqrt{ }$ & & & & & \\
\hline
\end{tabular}

\begin{tabular}{|c|c|c|}
\hline \multicolumn{3}{|c|}{ Method Preference } \\
\hline$\sqrt{ }$ High & - Medium & - Low \\
\hline
\end{tabular}


Six major technique categories are shown as accepted estimating methodologies. Many are known by other namos, for instance the bottoms-up tenhnique is also known as the definitive estimate techrique or as an Activity Based Cost (ABC) Estimate (non-capital activities). Some estimate types are based on a combinstion of techniques. For example, a Rough Order-of-Magnitude (ROM) estimste uses parametric, trend analysis, comparative and expert opinion techniques, depending on the scope to be estinated

\subsection{Rough Order-of-Magnitude (ROM) Method}

In the process of preparing an estimate for either bidding or tegotiation purposes, no substitute exists for using a detailed quantity take-off as a costing basis. Still, specific situations tray dictute a different approach, such as when the bigh cost of preparing the detailed estimate may outweigh the benefits received, or when time constraints do not allow a detajled estimate to be prepared. In those situntions, rough order-of-mageitude estimating may be the solution, since it allows a project's cost range to be obtrined in a relatively short period of time and at minimsl expense. ROM cost estimating may, thereforte, be delizied as a quick method of determining an approximale probable cost of a project without the benefit of detailed scope definition.

Rough order-of-magnitude estimates may be preparod for:

a establishing the probable costs of a program budget;

- evaluating the general feasibility of a project:

- evaluating cost consequenets of proposed design modifications,

- updating a previously prepared rough order-af-magnitude estimate;

- establishing a pretiminary budget for control purposes during the design phase; and

- screening a number of allernative projects so one or more can be given a more detailed examination.

ROM estimates are based on limited information and are thus subject to eonsiderable variation. Their accuracy also depends on the amount and quelity of information aveilable as well as the judgment and experience of tho estimator. Users must recognize these limitations and not "bang their hats" on the resultant estimates.

The ROM estimate category encompasses a number of methods. Several of the more commonly used methods are End-Product Units, Scale-of-Operations, various Ratio or Factor methods, end Physical Dimensions.

End-Product Units Method - This method is used when the estimator has enough historical dota availabte from experience on a particukar type of project to relate some end-produet units to construetion costs. This allows an estimate to be prepared for a similar project when the only major difference between the projects is their size. Examples of the relationship between construction cost and end-product units sre:

- The construction oost of an electric generating plant and the plant's capacity in kilowatts

- The construction cost of a hospitel and the number of beds

- The construction cost of an tank and the tank copecity

- The coustruction costs of a processing plant and the plant throughpout

Scale of Operation Method - This method uses historically derived empirical equations to oblain an estimate of approximate cost for different sizes of the same type industrial facility. This method is sometimes known as the six-tenths rule. A common form of this equation is: 


$$
\mathrm{C} 2=\mathrm{C} 1 *(\mathrm{Q} 2 / \mathrm{Q} 1) \mathrm{x}
$$

where: $\quad C 2=$ Cort of desired plant or piece of equipment

$\mathrm{Cl}=$ Krown cost of plant or pioce of equiptment

Q2 × Capacity of desired planl or itom

Q1 = Cepecity of known plant or item

$\mathrm{X}=$ Constant, usually in the range of 0.6 to 0.8

This mathematice] relationship reflects the now-linear increase in cost with size, and shows econouny of scale where the construction cost per unit of anpseity decreases as the project size increases.

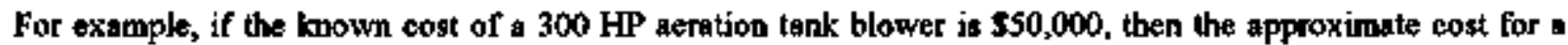
500 HP blower would be:

$$
\mathrm{C} 2=\$ 50,000 *(500 / 300), 8=\$ 75,000
$$

Ratio or Factor Methods. Many specialized Ratio or Factor methads are available to the estimator. Severa] of those typically used are described below.

Multiple of Equipmant Cost. This method is commonly used in constructing process and chemical plant where the cost of specialized equipment makes up a major portion of the total project cost. Approximnte project costs may be estimaled by totalling the cost of all mojor items of equipment and then multiplying this sum by a single ratio obtained from either bistorical data or other reliable sources. The estimate should be accurate form $+15 \%$ to $-30 \%$.

For example, if the total oost of all equipment for a chemical manufacturing plant is $\$ 10,000,000$ and the plant cost ratio (developed from reliable historical data) is 3.0 , then the estimated total cost will be:

$$
510,000,000 \times 5.0=\$ 50,000,000
$$

Lang Factors. Lang Factors are simply standard multipliers (factors) for use in specific situations. Sample factors are:

3.10 For solid process ptants

3.63 For solid tluid plants

4.74 For fluid process plants

Hand Factors. Hand Factors expand on the lang Foetors approach by using the individual components of permanent equipunent or systems. Each faclor converts the cost of the equipment item to its share of total construction cost (including labor, materials, construction equipment, and overhead). When all line items are factored and added together, the estimalor has a total estimate cost for the project. Some of the factors proposed for process plant equipanent are:

\subsection{For electric motors}

$4.8 \quad$ For instruments

4.0 For fractionating columns, pressure vessels, pumps, and instrumbents

3.5 For heat exchapgers

$2.5 \quad$ For compressors

2.0 For centrifuges 
The Physical Dimensions Methad This type of estimate is besed on physicel dimensions such as length, area, or volume. For instance, an estimate can be made for a building using the building's floor trea or its volurne; pipe lines, roadwaya and railroads maty be estimated on a limear basis.

The physical dimensions method depends on historical data from comparsble facilities. For example, to prepare an estimate using the square foot method, the total cont and square footage of one or more compartable structures must be known. The cost per square foot is obtained by dividing the lotat cost of the building by the number of square feet The coat of a new comparabie building is then estimated by multiplying the area of the proposed building by the cost per square foot obtained from the completed building(s).

\subsection{Bottoms-Up Teohnique}

The bottons-up tochnique is generally based on a work stalentent and set of drawings ot speoifications. This documentation is used to "take of (see definitions) muterials quantities required to perform each discrete activity. From these quantities, direct labor, equipment, subcontracts, and overhead costs are derived and added thereto.

\subsection{Specific Anslogy Techuique}

Specific analogies depend on the known cost of an item used in prior systems as the basis for the cost of a similar item in a new system. Adjustments are made to known costs to account for differences in relative complexities of performance, design, eperstional characteristics, or other quantifiable metasures.

\subsection{Parametric Technique}

Parametric estinnatiog requires historical databsses on simular systems or subsystems. Statistical analysis is performed on the data to find oorrelztions between sost drivens and other system perametera, suoh as design or performance. The andysis produces cost equtations or cost estinating relationships (CERs) which cen be used individually or grouped ibto more cornplex models.

This type of extimate, as the name implies, is based on certain parameters that reflect the size of scope of a project. Parametrio estimates are commonly used in the facilities constnuction industry for prepering approximate estimases. These estimates are usually prepared after the preliminary design phase is complete and the project's key features and dimensions have been defined. They can be roore accurate then other order-ofmagnitude estimates becouse the project on be broken down jnte more detait.

The first plase is the Dats Collection Phase. This phose consists of four main activities.

1. Describing the project in genergl terus, ineluding information such as:

- Type of facility (tank, inoinerator, power plant, office)

- Loeation (city and state)

- $\quad$ Project duration (starting and completion dates)

- Type of owner (goverument, private)

- Strictural paranselers (stainless steel, melal deck, reinforced concrete)

- Type of exterior walls (glass, anetal curtain wall, masonry)

- Special site conditions (rock excavation, dewatering)

2. Listing the standard paramelers that can be measured, such as the ones shown below, which are used by Enginoering News-Record in reporting parametrio costs:

- Gross enclosed floor area

- Gross area supported (excluding slab on grade) 


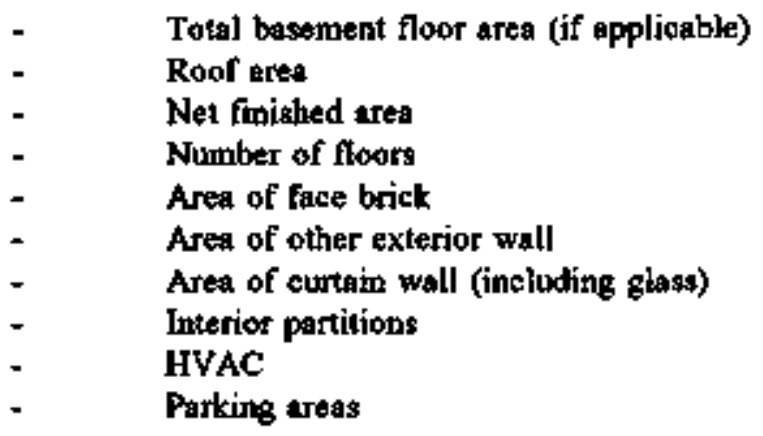

3. Establisbing opecific design chasecteristics relating to the type of structure which become additional parameters.

- Area of typical tloor

- Story beight, typical floor

- Entrance ares

- Number of plumbing fuxtures

- Number of elevalors

- Number of rooms

- Number of occupants

4. Determining selected design ratios which become additional parameters.

- $\quad A / C$ ton per building square foot

- Parking square foot pes building squace foot

- Plumbing tixtures per building square foot

The next phase is the Data Application Phase. The data applioation phase consists of tive main activities:

1. Listing trade sections or cost elements - the selected list must incorporate afl cost elements in the projoct.

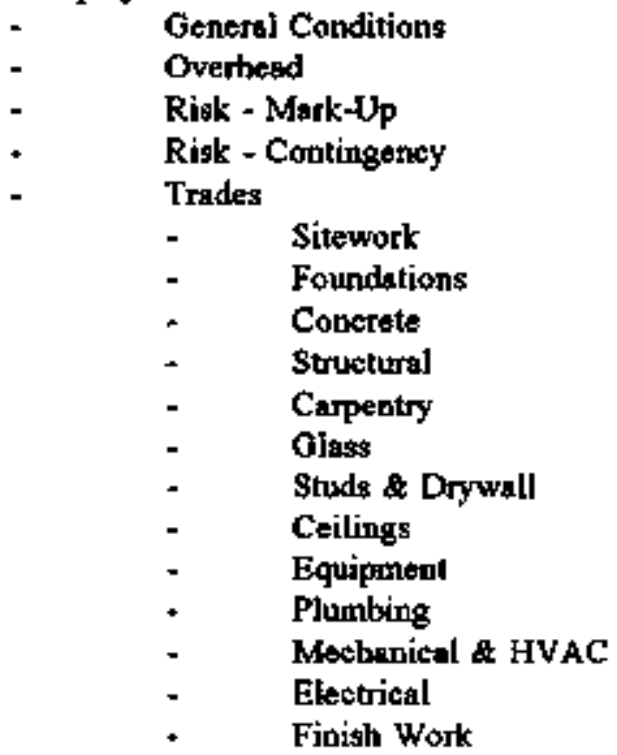

2. Listing the total cosk of each cost element from the reference project. 
3. Relaling each cost element to a parameter considered to affect its cost most alosely. This cobsists of assigning each olenent a code uumber (or parameter title) that corresponds to one of the parameters selected.

4. Determining cost elentent unit prices (wit prioes related to the selected perameters of the projoct). For exarmple, painting eosts may be considered most relaled to the square feet of net fipished area of a structure; the unit price is calculated by dividing aotual costs of the reference project by square feet of that project's net finished mrea (e.g., if total peinting costs $=\$ 6,000$; not (injshed area $=12,000 \mathrm{SF}$; unit price $=50.50 / \mathrm{SF}$ ).

5. Determining the percentage of each cost element expressed in terms of the entire projeot cost This is obxained by dividing the totsl amount for eech trade by the total project cost and multiplying the resule by 100. The resulting percentages, while not nomally used direotly in estimating a new project, are helpful in analyzing cost trends of the various cost elements among multiple projeots.

Once the above reference date is compiled, it asp be used to estimale a comparable new projoct. The new project is classified by the same cost elements used in the reference project, and the unit prices of the reference project are multiptied by the sctusal numiner of units on the pew project. For example, assuming the new project hes $10,000 \mathrm{SF}$ wet finished area, its painting costs would be estimated to be $\$ 5,000(10,000 \times \$ 0.50 / \mathrm{SF})$. This process would be ropented for all cost elements and the resulis totalled to generate a tatal estimated cost of the new project Still, the ostionator should consider adjusting the final estimate to refleet area and time oost indioes.

\subsection{Cost Review and Update Techrique}

An extimate is constructed by exemining previous estimates of the same project for inlertal logic, completerese of scope assumptions and estimating methodology. The estimales are then updaled to refleet the cost impect of now conditions or estimating approashes.

\subsection{Trend Analysis Techmiqut}

A contractor efficiency index is dorived by conparing originally projected contract costs agaimst actual costs on work performed to dale. The index is used to adjust the cost estimate of work not yet completed.

A cost index relates the cost of on jiem at one time and place to its cost at another time and place. The four main types of cost indices are:

- General Purpose Cost Indiess, such as those published by the Engineering Nows Record, the Department of Commerce, and the Bureau of Reslamation

- Contractor Price Indices, including those compiled by the Austin Companty, Fruin-Colnon, Tumer Construction Company, Suith Hinchman \& Grylls Associates, Inc., and H.F. Campbel]

- Vabation Indicen, such as those complied by the American Appraisal Company, Boeckh Coonpany, Marshall and Swift Services, and Handy-Whimmas

D Special Purpose Indices, including those cornpiled by Nelson Refinery, Port of New York Authority, the Environmental Protection Agency, the Bureau of Labor Statistics, and State Highway Departmenis 
Since the indices compiled by the Engineering News Record are probebly anong the most widely disseminoted, they will be discussed in the foilowing paragraphs.

The Engineering News Recond compiles and publishes the following three kinds of indices (among others):

- Construction Cost Indices

- Building Cost Indices

- Wage and Matorials Indices

These indices are compiled and published monthly, and reflect average costs from twenty cities in the United Stales and two cities in Canada. They are based on weighted skilled laber, structural steel, lumber, ard oement, and use a bese of $1913=100$; other presentations, such as the ENR Quarterly Cost Roundup issue where use a base of $1967=100$ is utsed.

To illustrate the use of cost indices, assume that the following information is available:

- A prospective olient contemplates building a warehouse in 1992 and wants an ordet-ofmagnitude estimate.

- An estimate is on file for a similar structure, conpleded in 1988 for $\$ 4,200,000$.

- The ENR index for 1988 building costs was 2600.

- The projected index for 1992 is 2850 .

- The estimated cost of a project of similar size will be: $(2850 / 2600) \times \$ 4,200,000=\$ 4,604,000$.

The estimator must know and understand the limitations that may exist on using indices in preparing order-of* magnieude estimates:

- A cost index is based on historical averages and does not take into account changes in technology that will naturally occur. For example, concrete bridgos and overpasses built twenty years ago are vastly different than those constructed today.

- Short-term economic cycle swings, ospecially in suall goographis areas, can be significent. Tberefore, indices oan lack sensitivity.

- There can be a reporting time-lag sssociated with the database, so a complex index containing many factors may not be representative of setul conditions at the time stated.

- A cost index database is a composite average and consequently bas a range of "accepalable" numbers associated with it. Even though most indices do not include that range, the estimator must be aware that it exists and securately judge when to adjust the index numbers used.

- The indusiry is awagh with cost indices, but the estimator has little, if any, information and guidelines for their use. Thus the estimatot must carefully document the use of an index so that others may have the same understanting of its use in that particular application.

A location index or city cost index relates the known cost of an item or project in one location to the same type of jtem or project in another location by using location indices such os those available through R.S. Means Censtructica Cost Data and Engineering News-Record.

\section{$3.7 \quad$ Expert Opinion Technique}

May be used when other techniques or data are not available. Several specialists can be consulted reiteratively until a consensus cost estimate is established. 
When a sost extimate is prepared for a project or program activity, a description of the basis for the cost estimate shall be mede and jocluded in the estimate documentation. The getweral roquirements for each type of cost estimate are included hereju.

\section{I Planning/Fensibility Study Estimateg}

The basis for the cost estimate stisll compriste a description of the project's purpose, rejation to the overall program mission, genersl design criterie, significant features and oomponents, proposed methods of accomplishment, proposed construction scbedule, reseatch and development requiremento, and any other pertinent cost experiences.

\subsection{Budget or Conceptual Design Estimntes}

These cost estimates shall be based on all the detailed requirements in the betget, pre-conceptual or ooncepanal desigh report (CDR) such as the design parametera, applionble codes, speoifications and standards. Qunlity assprance requirements, spece requirtments, texcarch and development requirements, methods of performanoe, operations interfaces, safety requirsments, and so forth, should be considered.

\subsection{Tile I Design Estimates}

The basis for these cost estimates shall include the CDR estinate basis, plus ail the refinements developed during the course of prodxcing the Title I engineering package. This inoludes all drawings, outline speofíioations, dath sheets, bills of malerial, sebedule refinements, definitions of scope, methods of performance, and ohanges in codes, standends, and specifications.

\subsection{Title II Design Estimates}

The basis for these cost ostimales shall include all the approved ongineering data, methods of performance, firal project definition and perameters, project sohedule, and final exact detailed requirements. The statement of "bssis" shall include a completo list of ell engineering data used; (i.e., drawing data shoets, specifications, bills of material, job instructions, proposod schodules, and so forth).

\subsection{Government or Engineers* Estimate}

Since this estimate is simply a refunement of a Tillo II design estimate, the basis used to make adjustments or refinements sholl be listed and mado part of the file.

\subsection{Current Working Estimates}

The besis for these cost estimates shall onrefully defipe the pirpose and scope of the estimate along with a complete list of ell the considerations used to develop the estimate for actual costs to date and for data used to omplete the projections.

\subsection{TWRS ESTIMATING AND THE DOE BUDGET AND PLANNING PROCESS}

The DOE budget cycle is based on the Congressional budget cycle, a three-year petiod that includes the Execution Year, the Buxget Year, and the Planning Year. The FYP and eorresponding Actjvity Data Sheets (ADSs) establishes budget for al] TWRS activities.

The DOE-HQ Five Year Plan covers a tive year period beginsing with the DOE Budget Year (current planning year plus two) and doesuments the requiremenls for the eurrent and next fiscal your. The current year (Execution 
Year) is oullined in the TWRS Fiscal Year Work Plan (FYWP). The Multi-Year Program Plan includes the Execution Year, the Budget Year, the Plenning Year and subsequent four yeers. The plans put into writing the steps, cost estimates and schedules required over the next five years to accomplish TWRS mission goals.

The betsis of the Five Year Plan process includes the preporation of the Activity Data Sheets (ADS) which describe in detail the budget requirements and milestonos of indjvidual activities. The ADSs are un integral part of the process DOE uses to prepare its budget request for Woste Management and Environmental Restoration and the way DOE \&liocates the funds provided by Congress. Budgets esteblished in the ADSs wilt go through an independent cost estimating valjdstion and review process (at DOE's request) to test the cosnpleteness and eccuracy of these funding requests.

\section{6* TWRS ESTMUTE DOCUMENTATION}

While it is recogrized that some programs/projects may not be able to nchieve in-full the docurnentation listed below due to that particular program's/project's maturity, the basis that supports TWRS funding requests must be provided and maintained throughout the life of the program/project and the lovel of detailed aupporting documentation must increase as the effort progresseg.

The funding leveis included in the ADSs must be surpported by documented and reviewed estimstes. Estimate documentation is essential to cost management including cost control, cost tracking, development and maintenarce of cost databases, and estimate validation processes. The level of information avajiable at the time the estimate is made determines the extent of documentation. The following recommended requirements are nat intended to reduose of limit any existing practices:

\subsection{Work Breakdown Structure (WBS)}

A WBS is a product-oriented description of the work and the reseurces required to complete an activity. A WBS is developed and used because it is * critical element in orgatizing the work and building cost and achedule estimates and is essential for reporting, tracking, and control.

\subsection{TWRS Estimate Work Sheets}

All Estimate Work Sheets and "roll-up" sheets for Total Estimated Cost (TEC), Total Project Cost (TPC), Operations Cost (OC), Levelof-Effort (LOE), indirect and overhead calculations, rist and/or contingency analysis, etc., are to be prepared and, as appropriate, spdaled and mainteined.

\subsection{Scope Descriptions}

A description of the scope of work, concept and/or task, that the estimale covers is to be documented on the Activity Planning Form and kept with the estimate. This includes both programmatic and project specifio requirements such as program objectives, funding probabilities, media and contaminants, regulatory consiraints, assumed tochnology, design, special capital equipment requirements, etc. If the work is a smaller component of a larger progrem/project, the estimate documentation includes a brief description of the larger program/project.

\subsection{Ground Rules and Assumptions}

Jdentify and document those costs imposed by eircumstances facing the program/project as well as those made by the estimator. Examples of those unposed by circumstances are funding constraints, changing regulatory requirements, dirocted changes or imposed priorities. Examples of those within the purview of the estimator include: 
Database source(s), estimating tool(s) used, materīal cost, wage rates, all umit costs including sampling and analytical costs, crew make-up, produsitivity, worker benefits included, and bandling of toxes.

The rationale for handling antioipated technology development, long-lead-time procurement, special studies, sequencing of tosks, imposed milestone requirements, vendor quotations, and resourde availability.

\subsection{Schedules and Milestoncs}

All activities are to be documented with identifiod milestones and detailed descriptions. Based on line organization guidance, activities will be resourco-loaded and time-phased to facilitate tracking, actunt vs. estimated. Activities are to be scheduted at the lowest feasibto level.

\subsection{Cost and Schedule Risk and Contingency}

Document the risks identified, how they were developed and the contingencies associated with each riak. 


\section{APPENDIX A}

\section{DEFINITIONS}

Acconnu Stromtnre. A formal organization of accounting codes used to collect costs for control account work which provides needed infornstion, segregated as necessary, for reporting costs.

Activity-Rined Cost (ABC) Entinnting consists of defining the overall takk(s) or activities and providing a unit of measute, quentity, labof-hours required, labor cost, material, subcontract, equipment usage, equipunemt, and overbead value(g) for that sotivity.

Activity or tstirate activities are defined in sufficient detail to identify components included in the estimbte. The antivity is defined in terms of a quantity of cost elements (e.g., quantity, labor-bours, labor cost, materials, sabcontracts, equipment usage, and overhead percentage)

Activity Datn Shacts (ADSs) are the principal planaing and budgeting informational link between the Fiekd Offices and Headguarters. The ADSs are used as a vehicle by EM Field Offices to develop and describe the various componeats of their progirans and to project budget needs to $H Q$. The ADSs provide information about scope of work, funding estimates, regulatory drivers, milestones, and other data. The ADSs are used and classified as budget fomalation documents becanse thay aro highly visible thronghout the entire budget cycle; as presentation materials to justify and verify ptogram-spesifie costs to OMB; and as budget execution documents. Accurate and prudent completion of the ADSs is imperative and results in an expedited nogotiations process.

Actine Cest. The Actual Cost of Work Performed (ACWP) is the cost incurred and recorded in the accounting system for accomplishing the work performed within a specifio time period.

Adranced Development is the effort guided by the principle that the work should lead ultimately to a perticular applieation or product. Advanced development can cut ecross several seientific disciplines end is intended to explore focused innovation in a particular area of one or more energy technologies.

Allowankes are additional tesources included in estimates to cover the cost of known but undefined requirements for an individual ^ctivity, work iten, account, or subaccounk. Used pringarily when litlle is kowows about proposed quantities or design crileria, end where activities calmot be defined in enough detail to salpport Activity Based Cost estimating.

Appliad Rexasch Systematic study directed towards fuller scientific knowledge or understanding for direct use in fulfilling specific TWRS requirements.

Authertzen Wudt Work that has been definitized and is included in the contract value as well as work that has been authorized in writing, but contract value has not been detersined and agreed

Bineline is a quantitative expression of projected costs, schedule, and technical requirements. Baseline establishment ghould include criterie to serve as a base or standard for measurement during the performance of as effort It is the data plan against which the status of resources and the progress of a project can be measured.

Bndrated Cint. The Budgeted Cost of Work Scheduled (BCWS) is the sam of buadgets for all tontrol sceounts for work scheduled to be sccomplished within a given time period.

Certified Coat Engheer (CCE) or Certified Cost Consultant (CCC) are cost engineering professionals 
recognized as such by AACE International (formenty the Americen Association of Cost Engincers). The certification reguires an examination and years of veriftable wort experience in the cosi enginecring fiek.

China Centrol. A docamented process applying technical end management review and approval of changes to lechnical, schedult, and cost baselimes.

Clange-Order is a dooument requesting a scope change or correction; a written change made by the architect/engineer or in-house engineering support to the contract drawings and/or specifications after the baseline has been set.

Graclc Stamute is a validating estimate. Its development and use is simitar to an independent cost estimate, except it is developed by program/ptoject or DOE Field Office personnel or their supporting entractor. A check estimate shoukd be doveloped by someone who had no involvement in the original estimate, but who may be an advocate of the project.

Confinesicy is an amount added to the cost estimate or schedule duration to sllow for chenges that experience strows will likely be required. This may be derived either through statistical or risk analysis of past-project costs or by applying experience gained on similar projects. Contingency usulelly does not include changes in sospe or unforeseeable major events such as strikes or earthquakes.

Coat Sutimate is a statement of costs estimased to be incurred in the conduct of an activity such as a program, or the eoquisition of a project or system. The cost estimate covers only the elements of a projest or affort included withis en agrees-upon scope. Cost estimates provide baselines against which cost eomperisons are made during the life of a project. The estimate can be in the form of proposals by contractors or Govemment agencies, a response to a program opportunity notice, or a DOE estimate. Methods for prepuring cost estimates are detailed in the methodology section of this cost gaide. Generally, each scheduled activity shall have a cost estimate.

Cont Estlmate Revien is a review of a previous estimale for compieteness, reasonbleness, and consistency. The completeness relates to the inclusion of all relevant costs. Reasonableness relates to a balance betwetn discemible optiznism and pessimisn in the estimate. Consistency reletes to the general acceptability of appliod grotmo tules or the employment of the same methods in going from one estimute to another. A reviow may be accomplished by comparing the estimate to an independent estimate; bowever, reviewers generally will not hove these available. Therefore, cost reviewers will generally use such tools os historitel rules of thumb to check unit prices, parametric cost estimating relstion ships, and sampling. Also, the estimate can be exarnined for appropriateness and consistency.

Censl|ance Reviaz. An assessment of the contractor's project management control system. The assessment normally occurs in two steps: . The contractor stubrits a description of its managounent control system to the Department of Energy (DOE) for review against specific applicable Project Control System Guidelines and the DOE Fiejd Office or Program Office Impiementation Plan; and b. A review team conducts a functional analysis of the contractor's system to delermine adberence to the pubtished description and integrity of contrator dats.

Cens diance Review Chatronan. The chairman is nomally a DOE Field Office or PSO representative. The chaiman is responsibłe for day-to-day activities. Typical activities include planning and schectuling the review, organizing and keading the review team, resolving identified system discrepancjes with the contractor, and preparing the review report.

Canolinge Revis Tenm. A team representing the DOE Field Office organization or PSO, as appropriate, which evaluates a contractor's projecl control systern. 
Conting is the process of using the take-off and the information presented in the scope documents to assign cost values to the telements of work previously cataloged.

Eecalation is post increase associated with unit price increase. Whereas the cost of projects can inerease because of poor management, scope growth, and sebedule delays; this cost estiulating guide, as well as DOE Order $5700.2 \mathrm{D}$, is ooncerned only with foreoasting price increaser caused by general or specific dollar devolustion. This is bistorically caused largely by an increase in the moum of currency in oirculation relative to the goods and services available.

Fired Cyats are those costs independent of stort term variations in output of the system under consideration. Generally seen as costs associsted with a plant at zero outpul or throughput.

Govemment Cata Eutimuty is an eatimate af oosts to be insurred in the conduct of proposed activity, prepared by DOE proponent (or advocate) by the measturable and defrinoble elentents of oost, consistent with the level that - responding contractor would be required to estimate, o.g., task, subtask, line item, and work breakdown struoture. It should be sufficiently documented to show clearly the ratiabeite used in developing the quantitative elements ss well as the rates. The Govenment cost eslimate usually is used as a tool in evaluating the reasonableness of the proposal(s) for the particular procurement aclion. This estirnate is generally performod to support negotiations and conpetitive bid proposals at the individual contrast level rather thap at the wotsi project level.

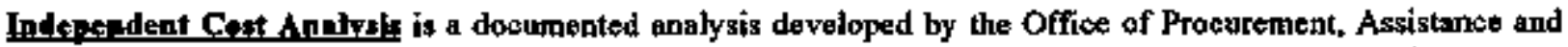
Program Management (PR-24) (or its contraotors) for the purpose of assessing the rensonableness of proponeat cost estimates and for identifying sensitive areas of cost risk. Gentrally, an independent cost estimate is accomplished and is used as a tool to preform an independent cost anafysis; bowever, sn independent cost andysis may be performed without first porforming an independent tost estimate.

Independent Cost Extimets is an estimste developed by PR-24 (or its contractors) that has the express purgase of serving as an analytical tool to validate, sross-cheok, or analyze estimates developed in proponency chantinels. An independent cost estimate also serves as a basis for verifying risk asseoments. The tern "independent cost estimate" in this cost guide mens independent of the project office or advocats. This cost guide does not usurp manager's prexogatives and responsibilities to direst check estimates (see below) to validate, improve, or seview surreat project estimates.

Interfoce Paint. The funclional, physical, or system characteristics at a common boundary between two or more project partisipants.

Laber Birden is the sum of the taxes and insurance costs based on labor payrelt that the employer pays on behalf of or for the benefit of its employees. These include social security, federal unemployment insurance tax, state unemployment tax, workers' compensation, holiday and vasstion scerual, company sponsored insurance programs, etc.

Labar Cogt is the tose salary, plus latwor burdens associated with habor, that can be definitely assigned to one activity, product, process, ot cost center.

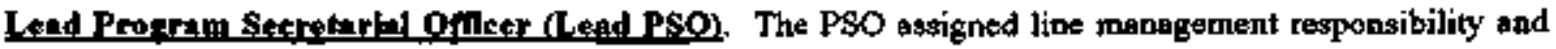
accountability for Headquarters and field operations and to which one or more multi-progran DOE Field Offices report direotly.

Lerel Of Efrort (LOE). Support effort that cannot be measured in terns of discrete aocomplishruent. LOE is chareaterized by a sustained rate of activity for a specific period of time. 
Life Cycle Cent is the total of the direct, indiroct, securring, nonrecurring, and other related costs incarred or estimated to be incurred in the design, development, production, operation, maintentence, support, deactivation, and/os disposition of a project or system over its anticipated useful life span. For exarnple, if a demonstration project is operated beyond the denonstration poriod, those costs are also inclubed in the life cycle cost estimate. Where system or project planning anticipates use of existing sites or facilitits, rosloration and refurbishment costs should be included.

Manerenent Rewerve (MR). That portion of the contract or project budget controlled by the coptractor for mapogement purposes and not designated for the sccomplisłunent of specific tssks; when MR is used it is distributed to specific acconts.

Milestone is an iaportant or critical ovent and/or activity thal must ocour in the project cycle in order to achiove the project objective(s).

Orpanizational Breakdara Sfructore (OHS). The hierarchical arrangemont for a company's management organization, graphically depicting the reporting relationships. Normally, the OBS is limited to showing only panagerial positions, but may depict lower organizalionel levols. The structure may also show subcontract relationships depending upon the purgose of the OBS.

Berformance Meannenent Bastine (PMB). The totel allocated budget less magagement reserve. It is the time phased budget plen against which contracl performance is formaliy measured. The performence measurement baseline includes budgets assigned to control accounts and undistributed budgets.

Pricies is the determination of the amount to be charged to the DOE so as to fully include dineel and indiret cost items as well as contingency and profit. See also Oovernment Cost Estimate.

Prolect. A unique major effort within a program which has firmly scheduled beginning, internediate, and ending date milestones; prescribed performance requirements, presetibed costs; and close management, planning. and control. A project is a basic building blook in relation to a program which is individually planned, approved, and managed. A project is not constrained to any specific elensent of the budget structure (e.g." operating expense or plant and copital equipment). Construction, if required, is pert of the total project. Authorized, and at least partially approprialed, project will be divided into three categories: MSAs, Major Projeots, and Other Projects.

Prolest Centrel Syatem. The plonning, scheduling, budgeting, estimating, work authorization, cost accumpulation, performance measurement, reporting chenge control, and other systems used by a contractor to plan and conitrol the work

Project Control Systen Guidelines. DOE established characteristics that contractors' internil mansgement control systems paust possess to assure effective planning. managennent, and control of projects and contracts.

Priect Contmol Sratem Guidelines leplementation Plan. A DOE Field Orfice or PSO plan for imptementing the Project Control System Gujdelines. The plan includes implementation policy, describes the graded application of guideline elemenss to projects and contracts, delineates responsibilities, and outlines the compliance review process.

Prolact Riily A factor, element, constraint, or course of action on a project that introduces an uncertainty of outcome and the possibitity of technical deffeiexcies, inadequate performance, schedule delays, or cost overnins which could impact $\$$ Departmental mission. Evaluation of project risk must consider the potential impact and the probability of occurrence.

Scope is the equipment and materials to be provided, and the work to be done. Scope is documented by the 
contract parameters for a project to which the company is committed. In boseline management terminology, the term "scope" refers to those performance and design requirements, oriteria, and characteristics derived from technical mission neds that provide the basis for project direction and execution.

Sched.le Baneling. The time pbesed ptan with a logical sequence of interdependent activities, milestones and events necessary to omplete the project. The schedule baseline shall be formally ohanged during the execution of the projoct when required.

Sen-Variable Corth are costs that are pertially fixed (independent of production level) and are partially variable (dependent upon production level). Fuels which are used for spece beat and production would be semivarisble, as well as maintenance, general expense, and plant overhead costs are ustally somj-variable. It is estimated that semi-variable costs at zero production are 20-40 persent of the semi-variable costs at full peoduction. See also variable costs, fixed costs.

Trke-Oef is the process of measuring and cataloging the quantities of work derived from the scope documents.

Testmical Bntuline. A configuration identification document or set of documenta formally designated and approved by DOE. The Conceptual Design Report (CDR) will become the initial project technieal baseline. The initial technical baseline, plus DOE approved changes to that baseline, constitutes the eurrent technical baseline.

Totel Allwested Bndgat (TAB). The sume of all budgets ellocated to the contract or project, as applicable. Totai Alloceted Budget consists of the perfornance messurement baseline plus managentent reserve.

Tntal Fentinnted Cont (TEC) is the construetion costs of the project, including: the costs of fand and land rights, enginetering, desiga, and imopection costs; direct and indirect conatnuction costs; and initial equipment necessary to place the plant or installation in operation.

Tafal Project Ceat (TPC) is all generic rezearch and development, operating, and plant and oepital costs specifically essociated with s project. It is the stru of the total estimated cost plus all other costs identifiable 10 the project. Project costs are mutually exolusive; i.e., if sesearsh and development is required to complete a given project that is elso supporting a secoud follow-on project, the cost will only be charged to the first project. If the first project should be terningted, the curnulative costs of research and developinent support to that point will be considered strok costs, and all cosis from that point forward would be charged to the follow-on project. fn no instance shoild the same research and development costs be charged to mort than one project.

Wadlutrilunted Budget (UB). Budget within the porformance measurement baseline applicable to the work effort that bas not yet boen identified to both a responsible organization and a WBS element.

Validation is the process of evaluating project planning, development, baselines and funding prior to imolusion of funds for a project or system acquisition in the DOE budget. It reguires a review of project plenning and conceptual development documentation, as well as discussion with the progran or field element and principle contributing contractors to determine the saurce basis, procedures, and validity of propased requirements,scope. cost, schedole, funding, and so forth. Finfings and rocommendations resulting from the validation process will be provided for use in the anmual budget formulation

Varits.e Centif are the cosis that are a function of production, e.g, raw malenial costs, by-product credils, and those processing costs that vary with outpul (such as utilities, catslysts and chenicals, packaging, and labor for batch operations. See elso Serni-Variablo Costs.

Vyriance. The difference between plonsed and actual performance. Variances that exceed established 
threstrolds should be revised during the life of a project to ensure meaningful anulysis.

Work Antharization. A oontrastor's internally documented process or system that ensures work is property authorized and assigned at the appropriate organizational levels prior to beginning the work.

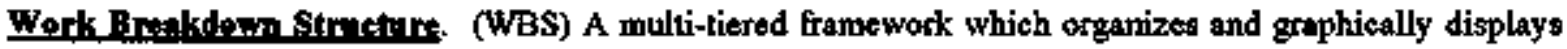
elements representing work to be accotylished in logical relationships. The WBS nay or may not be productoriemted; orientation may be towards products, projeot phases, key decision points, various budgeting umits of measure, e.g., activity data sterets, or a combination. The WBS should be organized such that each element sen be estimated, scheculed, badgeted, and work progress reported.

Work Pockne. Subdivisions of the lowest level WBS element accorded detriled soope, schedule (start and completion points), budget, a description of seope (including activities) and respontsible mantager. 


\section{APPENDLX B}

SAMPLE ESTIMATE 


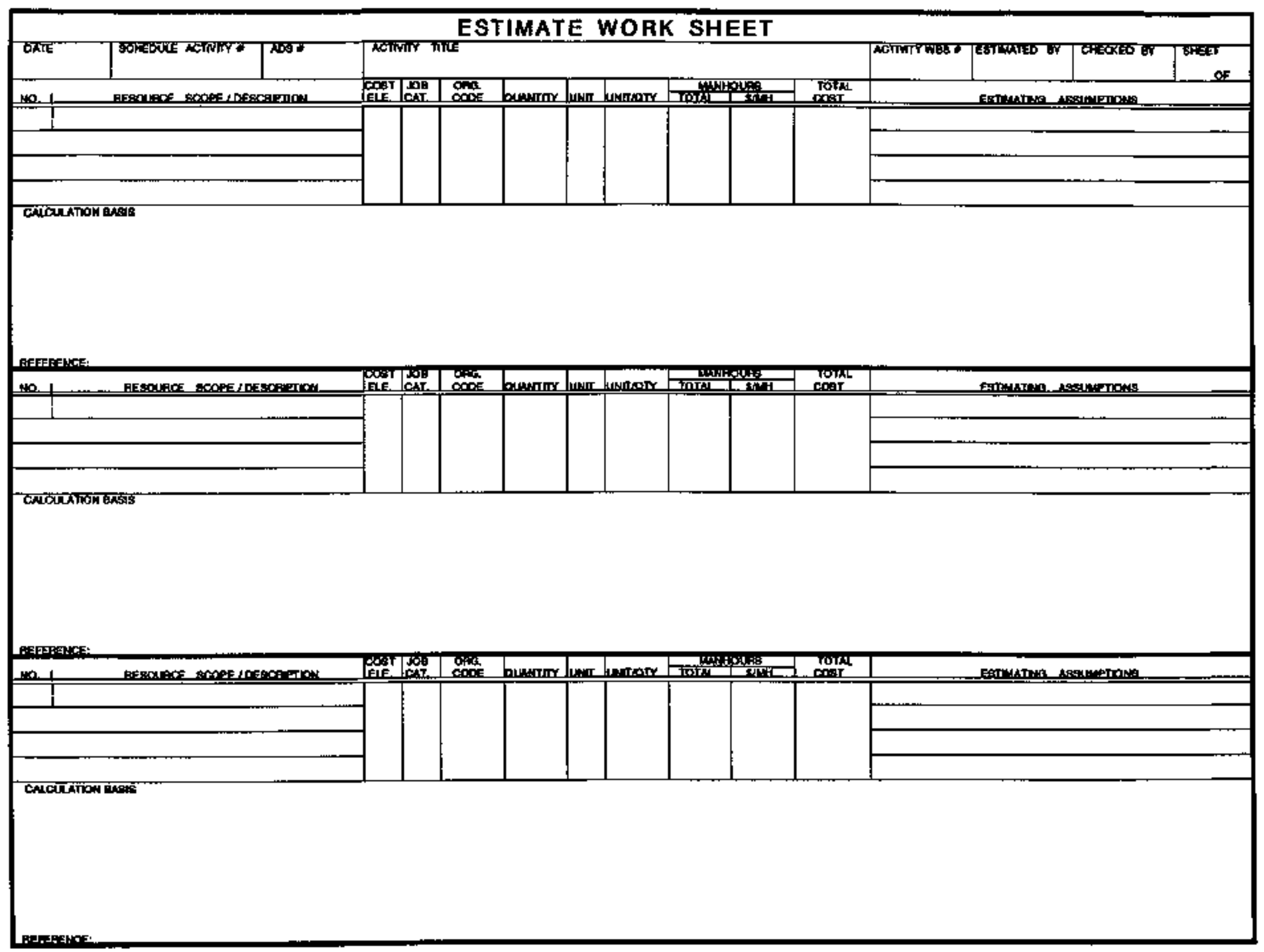




\section{APPENDLX C}

\section{BIBLIOGRAPHY}

Stills \& Knowledae of Cost Enpinetring. Third Edition

Amerionn Association of Cost Engineers, Morgantown, WV, 1992

Humphreys, K. and Wellman, P. Bgsic Cort Engineetinta Second Edition

Marcel Dekker. 1987

Jelen, F. and Black, J., Cost and Optimization Enaineering Second Edition

MeGow-Hill, 1983

Selg, R., Hazardoug Waste Cost Controls, Firat Edition, Marcel Dekker, 1993

Broject Control System Guidelines, of 8.72.92

DOE N 4700.5

Projest Management Systegn. with changes as of 6-2-92

DOE Order $\mathbf{4 7 0 0 . 1}$

Cost Estimating, Antysis and Standardization. of 6-12-92

DOE Onder 5700.20

Cost Guide. Volume 6: "Cost Estimating Methods and Techuiques", of 5.82 DOEMA-0063

Cost Estimating and Roview Guidance for the FY 1994-1998 Five-Year Plan

U.S. Department of Energy

Office of Warte Menagement (EM-30) Cost and Sebodule Estimating Guide. Working Draft. 12/8/92. 


\section{U.S. Department of Energy DOE Hanford Reservation}

Tank Waste Remediation System

(TWRS)

Operations

\section{COST ESTIMATING GUIDE}

Draft 1.0

January, 1993 


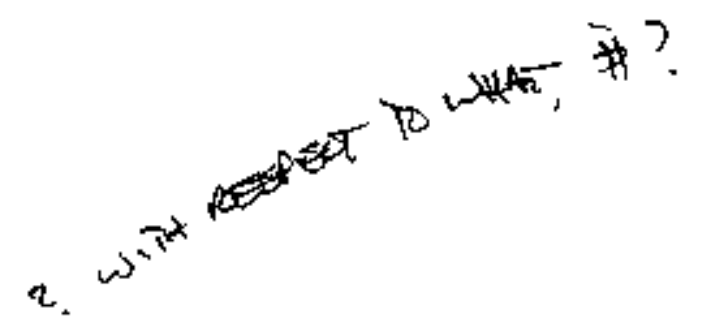

\section{$1.0 \quad$ INTRODUCTION}

Purpose of the TWRS Operations Specifle Cost Bftimating Guide

The activities associated with the Tank Waste Remediation System (TWRS) at Hanford include both project and program efforts that arevage and complex. Planning for the future at TWRS is a challenging task; risk areas such as regulations, technologies, management practices and other changes and uncertainties all ans an integral part of 7 TWRS. The purpose of this guide is to delineate the estimating activities required in support of TWRS and facilitate implementation of the recently promulgated EM-30 Cost and Schedule Estimating Guiden the TWRS-Program:--

Two major points are made relative to the EM-30 Cost Guide from Headquarters. First, the Headquarters Guide is the primary tool for development of TWRS estimates. Sections of the Headquurters Guide, especially those that relate to estimating methods and Activity Based Costing (ABC), will not be restated in the TWRS Guide. The intent of the T'TWRS Guide is to "tier under" the HQ Guide to be more responsive to TWRS. Second, the TWRS Guide is intended to cover only ongoing and planned oporatens activities at TWRS, and not projects. Projects in the DOE realm have been successfully governed by well established DOE Orders and procedures for some time, and the control mechanisms do not need restatement here.

The ultimate purpose of this Guide is to supply the necessary direction to prepare defensible, credible TWRS cost estimates. These estimates can then undergo review scrutiny, be rolled up to feed the budget process, and survive to form the basis of a historical track record of TWRS changes and decisions. The purpose of inclusion of the review criteria is to internally check estimate development performance in a TWRS self-assessment program and to improve estimate quality on an ongoing. iterative basis.

\section{Intended Audience}

The the Tank Waste Remediation System Division of We Westinghouse Hanford Company. This guide is to be used by the Deferivision or their associated subcontractors as a working document and estimate preparation reference. Estimators, schedulers, cost account managers (CAMs), end function managers and program? practical management feference tool. 


\title{
TWRS Cost Estimoting Guids Draft 1.0
}

\section{Introduction to TWRS Operations Estimating}

The benefits of initiating complete estimates are both short and long term. Initially, just the process of an activity by activity look at the TWRS Program will fesult in better planning and dexisiorfmaking by both the contractor and DOE. This has already occurred to some degree by the initiation of resource-loaded scheduling techniques on TWRS, and has produced positive results. Increased likelihood of programmatic funding and budget approval is also a positive outcome of adaptation of the DOE EM-30 operation estimating methodology. Long term, the benefits of better program management and performance measurement, as well as the collection and use of historical cost data, will substantially improve the overall program.

\begin{abstract}
tgivities
Operatiensare defined as the atetivities required to plan, manage, operate, produce, manufacture, store, treat, transfer and maintain existing or planned facilities, waste, materials and infrastructure. The construction of a new facility is treated under DOE definition as a project, but the initial planning of the facility is a programmatic activity. Research and development (R\&D) activities, such as those required for new TWRS preftreatment technologies, are also operations activities. The areas of a project life-cycle that are considered to be subject to TWRS operations estimating are shown in Figure 1. This "block diagram" illustrates the activities subject to operations estimates and are covered in this guide.
\end{abstract}

[[FIGURE 1 Here gph3.dwg insert 6.0 X 6.5]

Coupled with the brief definition of operations, an introduction to estimating is also in order here. Remember, however trite, that an estimate is an estimate. The activity of prodicting future events and associated costs is bott an art and a science. The better estimates are based on better predictions. Prediction is based on the ability to assimilate history, experience and judgement in a format that is easy to communicate and understand. The EM-30 Headquarters Guide discusses the concept of Activity Based Costing (ABC) in detail. This concept, introduced in November, 1991 by EM-30, utilizos common estimating techniques and methods borrowed from the construction industry and applies those to 6 poritions. For example, one of the first planning activities is to develop a Work Breakdown Structure (WBS) for the opertivities to be executed. Until recently, a WBS was not seen in the operations planning arens at a level for estimation.?

A stated responsibility in the WHC TWRS Division Charter (September 3, 1992) is to "manage plants and facilities cost-effectively and in compliance with applicable nuclear facility operating standards". The key to cost effective management is cost effective planning. 


\section{TWRS Cost Extimating Guide}

Draft 1.0

The following sections discusps the necessary components of general requirements, scopes, schedules, estimates and self-assessment activities to allow TWRS the mechanisms for sound planning

\subsection{GENERAL REQUIRFMENTS}

\section{Overall Milusion}

[Adapt from TWRS Division Charter OR obtain from DOE=RL or WHC?]

\section{Master Schedule}

[ History from Renee]

\section{Madtar WBS}

[Top dewn meets bottom up - explain]

\section{Overall Estimate Managewent}

The use of an estimate update log is required for continuity of planning. This log can also show a reviewer why an estimate was updated, as well as other important update data. The log should look like the one illustrated in Figure 2. Note that the log will stay. with the original estimate and estimate file. If the work is later split, or organization, the log should note that and be split as well. The log sheet should also note reviews and findings as illustrated.

[Figure 2 - sph4b,dwg estimate log sample]

\subsection{SCOPING TWRS ACTTVTIES}

Includes the importance of estimate back-up documentation, the type of information required, and the formats for input.

\subsection{SCHEDULING TWRS ACTIVITIES}

This section covers scheduling as it relates to estimating process. In-depth discussion of schediling will not be addressed.

\subsection{ESTLMATING TWRS ACTIVITIES}


TWRS Cost Estimating Guide

Draft 1.0
[ABC Approach
What's ressonable for TWRS?
Use block diagram again - Gph3.dwg
RPM module]

[ Angment EM-30 approach with TWRS approach from resource loaded schedules ]

\subsection{TWRS SLLF-ASSRSSMDNT CRITERLA AND PROCWSS}

This section deals with the new peer review concept and sets up criteria for checking the completeness and quality of the TWRS estimates.

[ Insert Updated Criteria and blend w/ EM-30 Cost Guide Appendix]

[Bring in Ops ICE and benchmarking process]

7,0 IXAMPLE MSTMATE

A TWRS estimate, on the appropriate forms, will be included to illustrate the concepts outlined in the guide. Intended as a step approach.]

[NOTE: This is roughed out - need to word process 1/7/93]

\section{APPENDIX A}

\section{TWRS ACTIVITY DICTIONARY}

[Code of Accounts for Std activities plus descriptors]

[Incl CDRs, ORRs and other std configuration TWRS activities]

[Gary do???] 
February 22, 1993

Environmental Restoration Technical Support Office (ER-TSO)

Los Alamos National Laboratory

P.O. Box I663, MS J493

Los Alamos, New Mexico 87545

Attention: Mr. Gary Thompson

\section{Dear Gary:}

I received a request last Thursday for the disks and back-up documentation for the two manuals I prepared in first draft for TWRS from Renee Finke, Westinghouse Hanford. These two guides were delivered to you and Renee on the requested due date of January 29, 1993 (see enclosed cover letter). I was issued a stop work order from Los Alamos National Laboratory (LANL) on that dale, pending a contract with TWRS to continue working on the agreed upon scope, which included the bulk of the work to tinalize these guides.

I did receive one set of comments back from Bill Edwards, DOE-RL during the week of February L, 1993. Since the authorized contract was through LANL, I was asked by you to have the comments semt to LANL instead of to me directly. To date, I have not received any additional comments through that arrangement.

I am not aware of any contract proceedings on continuance of this work. Based on the stop work order, the request for the disks, and the lack of comments on the first drafts, I an concluding that no desire exists to continue this work for TWRS. Could you please verify that Project Time \& Cost, Inc. is no longer requested?

Athough I have relayed the following concent verbally to both Renee Finke and Bill Edwards, I feel that it is necessary to transcribe my opinion of expectations on the quality of the first draft. When I last spoke to Bill, he used works like "salvageable" and "non-working document" and indicated that, with immediate response, it may be possible to "rescue" the cost guide. With less than 100 manhours of effort on both of these documents, and the redirection of the initial start of the guides by Gene Higgins in our meeting of January 6, 1993. I felt that the first draft of these geides represented both a good faith effort and a Jogical starting point. DOE curtently has less that $10 \mathrm{~K}$ invested in the guides. For perspective, the recently promulgated EM-30 Cost Guide represents an investment by DOE of over one-half million dollars to date. In order to complete these guides, additional time must be spent incorporating comments and detailing a "how to" path to estimate activities within TWRS. In summary, DOE-RL did receive a fair value product for the monies invested. 


\section{Project Time \& Cost}

Mr. Gary Thompson

February 22, 1993

Page Two

I have indicated in a phone conversation last Friday with Renee Finke that the request for the disks must come from LANL. She has indicated a desire to obtain the disks as soon as possible. I am awaiting your direction on both the continuance of the project and the request from Renee.

Sincerely,

PROJECT TIME \& COST, INC.

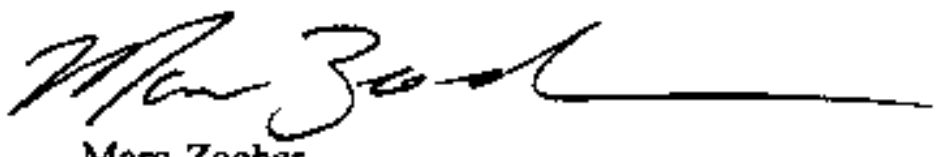

Marc Zocher

Manager, Western Operations

cc: w/Enclosure

Gene Broks, PT\&C

Ken Roberts, PT\&C

Renee Finke, WHC

Gene Higgins, DOE-RL

Bill Edwards, DOE-RL

Jim Turi, DOE EM-33 
Informal Hote

February 26, 1993

TO: Prasod Mall1ck

FRON: Warc Zocher, 3

RE: Progran Cost Review Schedule - First Cut

Attached is the first cut at scheduling the Progran Cost Reviews (PCR). I have toid the Program Managers that we are trying to firm up a schedule by March 5, 1993 in order to make team assignments and handle logistics (e.g., security).

I whll be calling next week to complete this schedule. If you have questions, please contact me. 
Program Cost Reviews

Oraft Review Dates

as of February 26, 1993

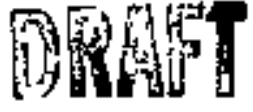

\begin{tabular}{|c|c|c|c|c|}
\hline SITE & HQ CONTACT(S) & HQ PHONE & REVIEN DATES & TEAN \\
\hline DOE AL (AL ADSS) & GEORGE KLIPA & $3-7129$ & $4 / 22$ & TBD \\
\hline HIPP & $\begin{array}{l}\text { DOUG TOHKAY } \\
\text { ED WADE }\end{array}$ & $\begin{array}{r}3-7212 \\
3-7207 \\
\end{array}$ & $4 / 8-4 / 9$ & TBD \\
\hline LOS ALAMOS & PETE SIEBACH & $3-7128$ & $4 / 14-4 / 16$ & TBO \\
\hline SAMDIA NM (+ITRI) & PETE SIEBACH & $3-7128$ & $4 / 12-4 / 14$ & TBO \\
\hline SAMDIA CA & JANE TALARICO & $3-713 I$ & $4 / 19$ & TOO \\
\hline PAMTEX. & GEORGE KLIPA & $3-7129$ & $4 / 19 \cdot 4 / 20$ & TBO \\
\hline GRAND JUNCTION & GEORGE KLIPA & $3-7129$ & $4 / 22$ & TBD \\
\hline KANSAS GITY & GEORGE KLIPA & $3-7129$ & $4 / 21$ & TBD \\
\hline MOUHD & JANE TALARICO & $3-7131$ & $4 / 20-421$ & TBD \\
\hline DOE CH & MARY BURANOT & $3-7113$ & $T B D$ & TBD \\
\hline DOE SAH & GORDOH LANGLIE & $3-7119$ & $\mathrm{TBD}$ & $T B D$ \\
\hline DOE NY & WARREN BLACK & 3-7122 & $4 / 28-4 / 29$ & TBD \\
\hline DOE OR & $\begin{array}{l}\text { MICHAEL TORBERT } \\
\text { BRIAN WESTICH } \\
\text { CARL PIIJ } \\
\end{array}$ & $\begin{array}{l}3-7109 \\
3-7110 \\
3-7998 \\
\end{array}$ & $4 / 12-4 / 16$ & TBD \\
\hline DOE SR & JEHMIFER SANDS & $3-7115$ & $4 / 12-4 / 16$ & $\mathrm{TBD}$ \\
\hline $\begin{array}{l}\text { DOE RL } \\
\text { (+TWRS) }\end{array}$ & $\begin{array}{l}\text { GENE CHOU } \\
\text { ANDY GRIFFIJH } \\
\text { JIN KEENAN } \\
\text { RICK MARTINEZ } \\
+ \text { EM-36 } \\
\end{array}$ & $\begin{array}{l}3-7159 \\
3-7120 \\
3-7121 \\
3-7648\end{array}$ & $4 / 26 \cdot 4 / 30$ & TBD, MULTIPLE \\
\hline DOE ID & JOHA NEAVE & 3.7678 & $4 / 5-4 / 6$ or $4 / 19-4 / 20$ & TBO \\
\hline DOE RF & $\begin{array}{l}\text { ROBIY SWEENEY } \\
\text { RON DUVALL }\end{array}$ & $3-7991$ & $4 / 5-4 / 7$ & TBO \\
\hline
\end{tabular}

